\title{
The Usefulness of Mixtures with Festulolium braunii for the Regeneration of Grassland under Progressive Climate Change
}

\author{
Teodor Kitczak ${ }^{1}$, Heidi Jänicke ${ }^{2}$, Marek Bury ${ }^{3}$ (i) and Ryszard Malinowski ${ }^{1, *(1)}$ \\ 1 Department of Environmental Management, West Pomeranian University of Technology Szczecin, \\ Słowackiego 17 Street, 71-434 Szczecin, Poland; teodor.kitczak@zut.edu.pl \\ 2 Landesforschungsanstalt für Landwirtschaft und Fischerei MV, 18196 Dummerstorf, Germany; \\ h.jaenicke@lfa.mvnet.de \\ 3 Department of Agroengineering, West Pomeranian University of Technology Szczecin, Słowackiego 17 Street, \\ 71-434 Szczecin, Poland; marek.bury@zut.edu.pl \\ * Correspondence: Ryszard.Malinowski@zut.edu.pl; Tel.: +48-91-449-6389
}

Citation: Kitczak, T.; Jänicke, H.; Bury, M.; Malinowski, R. The Usefulness of Mixtures with Festulolium braunii for the Regeneration of Grassland under Progressive Climate Change. Agriculture 2021, 11, 537. https:/ / doi.org/10.3390/agriculture11060537

Academic Editor: Marco Mariotti

Received: 27 April 2021

Accepted: 8 June 2021

Published: 10 June 2021

Publisher's Note: MDPI stays neutral with regard to jurisdictional claims in published maps and institutional affiliations.

Copyright: (c) 2021 by the authors. Licensee MDPI, Basel, Switzerland. This article is an open access article distributed under the terms and conditions of the Creative Commons Attribution (CC BY) license (https:// creativecommons.org/licenses/by/ $4.0 /)$.

\begin{abstract}
The climate warming and changes in weather patterns in Europe are negatively affecting the structure of grassland swards. The disappearance of valuable forage grasses can be observed. Therefore, in order to keep grassland productivity high, high-yielding grasses of good quality that are resistant to changes in the weather are being sought. At the moment there are few publications which present the long-term influence of changing weather conditions on meadow sward structure and its fodder value. This study aimed to assess the suitability of grass mixtures with Festulolium braunii for grassland renewal by full tillage on organic soil, taking into account atmospheric conditions. The experiments were carried out in the years 2009-2018 on a meadow complex located on organic soil in the Randow river valley, near Ramin (Germany). Grassland restoration was carried out by the method of full cultivation in three experiments with different proportions of Festulolium braunii and Lolium perenne (the existing grassland was eliminated and seeds of a new grass mix were sown). The meadow experiments were established using the method of random blocks in four repetitions Detailed studies included: floristic composition of meadow sward, fresh and dry mass yields, and content of: crude protein, soluble sugars, raw fiber, and net energy NEL (net energy lactation) concentration. Festulolium braunii, Poa pratensis, Dactylis glomerata, and Phleum pratense proved to be more resistant to low temperatures in winter and excess water in spring than Lolium perenne. The largest production potential of fresh and dry mass was found in mixtures with a high content of Festulolium braunii Festulolium braunii tolerates varied and unfavorable weather conditions (frosts during snowless winters, spring frosts and waterlogging, and droughts) very well and provides a stable good quality sward yield (favourably affected the carbohydrate and protein content of the sward). Lolium perenne, on the other hand, decreases its share in the sward under unfavorable weather conditions.
\end{abstract}

Keywords: grass mixtures; yields; chemical composition; floristic composition; climate change

\section{Highlights:}

1. Festulolium braunii tolerates varied and unfavorable weather conditions (frosts during snowless winters, spring frosts and waterlogging, and droughts).

2. Lolilum perenne decreases its share in the meadow sward under unfavorable weather conditions.

3. A higher share of Festulolium braunii in the meadow sward has a favorable effect on the carbohydrate and protein content of the sward.

\section{Introduction}

In recent decades there has been a noticeable warming of the Earth's climate. It is associated with changes in weather patterns, e.g., in the distribution and amount of 
precipitation, cloud cover, atmospheric and oceanic circulation, frequency and intensity of violent weather events [1]. The cause of global warming is anthropogenic activity and associated greenhouse gas emissions. The main greenhouse gas is carbon dioxide, which accounts for $19 \%$ of the greenhouse effect, and others such as methane, nitrous oxide, ozone, sulphates, nitrates, particulates account for less than $7 \%$ [2]. The concentration of $\mathrm{CO}_{2}$ in the atmosphere has increased from $280 \mathrm{ppm}$ at the beginning of the industrial era (mid-1800 s) to $455 \mathrm{ppm}$ today [3]. It is estimated that the global temperature is currently 0.9-1.3 ${ }^{\circ} \mathrm{C}$ higher than it was between 1850 and 1900 [4]. According to the [5], by the end of the 21 st century the average temperature is expected to rise by a further $0.3-1.7^{\circ} \mathrm{C}$. Hughes [6] predicts that as the climate continues to warm there will be: a greater increase in winter than summer and night than day temperatures, an increase in average precipitation but a reduction in some areas, and an increase in extreme precipitation. These changes will affect plant development (photosynthesis, respiration, biomass production and plant chemical composition), distribution and range, and phenology [6-9]. It is recognised that the evolution of flora has been highly dependent on atmospheric $\mathrm{CO}_{2}$ content and temperature [10].

Climate change may significantly affect the structure of grasslands and their functions in the ecosystem. Permanent grasslands occupy over $23 \%$ of land areas and perform important functions in the natural environment: landscape, climatic, hydrological, filtration, phytosanitary, protective, maintenance of biodiversity and balance in the natural environment. Moreover, they have an important role in shaping soil fertility (humus and nutrient accumulation, improvement of structural and microbiological properties, protection against erosion). They also have an important production function - they are a source of natural and valuable fodder rich in protein, carbohydrates, minerals, vitamins, carotene, lecithin enzymes and other substances. Among the different grasslands, only permanent grasslands combine natural, protective and agricultural values without harming the natural environment. Progressive climate change may contribute to a decrease in the area and degree of use of permanent grasslands, which will result in impairment of their natural and productive functions [11]. Accelerating climate change is already affecting vegetation, phytoplankton, mammals and insects $[6,10]$.

The level and quality of yields from grasslands depend on many factors, such as weather conditions, habitat and the floristic composition of the sward [12,13]. In recent years, due to climatic changes, mild winters during which there are short rapid frosts, long periods of drought, periodic rapid rainfall and a marked increase in annual temperature have been observed [14-18]. Especially unfavorable for meadow sward persistence are sudden temperature drops during mild snowless winters and prolonged droughts during the growing season. Increasing climate warming is projected to threaten many plant species found in Europe [19], but also to affect the quality of crops [20].

It has been shown experimentally that an increase in atmospheric carbon dioxide will increase biomass and increase water-soluble carbohydrates and decrease nitrogen in meadow swards [21-23]. In addition, C3 plants to which temperate zone grasses belong, at higher than current $\mathrm{CO}_{2}$ concentrations, increase resistance to drought, less sunlight and low nutrient availability. Mitchell et al. [24] found increased pathogen abundance on C3 grasses at elevated $\mathrm{CO}_{2}$. It appears that the increase in atmospheric $\mathrm{CO}_{2}$ will not itself have as strong effect on temperate zone plant communities as changes in weather conditions, especially sudden extreme events.

Climate change is already resulting in reduced productivity of permanent grasslands $[22,25,26]$. This problem is particularly acute in organic soils (peats, muck), which undergo rapid mineralization processes when excessively dry, resulting in changes in their physical and chemical properties [27]. The negative impact of water deficit on meadow vegetation development is highlighted in the research literature [28-31].

Grasses intended for mowing on peat-muck soils, only shortly after sowing, are characterized by a stable species composition [32,33]. High grasses (higher than $100 \mathrm{~cm}$ ) are the first to disappear (Festuca pratense, Phleum pratense, Dactylis glomerata), and their 
place is taken by Poa pratensis. The conversion processes in these habitats are intensified by the progressing climatic changes. Therefore, there is a need to conduct research with the selection of grass species for meadow mixtures on organic soils [34,35].

In recent years, due to climate change, there has been increasing interest in forgotten grass species and grass hybrids in many countries. Interspecific hybrids have intermediate parental characteristics - high yields of good quality and resistance to unfavorable habitat conditions. Festulolium braunii hybrids obtained from crossing meadow fescue and perennial ryegrass are one of them [36-38]. Festulolium braunii hybrids are characterized by high productivity and persistence in sward [39-44]. They respond well to drought, frost and periodic excessive moisture [38,45-49]. However, some studies indicate that prolonged drought may limit the growth of some Festulolium hybrids [50,51]. Festulolium braunii is used with mixtures for alternate grassland and used for renovation of permanent grasslands [52-55]. The meadows have consisted so far of a mixture of high-yielding grasses, but are demanding in terms of habitat, fertilisation and specific climatic conditions. These grasses adapt poorly to weather changes and disappear from the meadow sward, which is confirmed by field observations. Therefore, it is important for agricultural practice to develop alternative meadow sward mixtures with good fodder value and at the same time adapted to periodic summer drought, high humidity in winter and spring, and warm, snowless winters with short but strong frosts, and responding well to increases in atmospheric $\mathrm{CO}_{2}$. These conditions can be met by hybrids of appropriately selected grasses. The suitability of hybrids in shaping the height and quality of sward yields should be tested under different habitat and weather conditions over a sufficiently long period of time.

The aim of the study was to assess the suitability of grass mixtures with different proportions of the Festulolium braunii hybrid for grassland renewal on organic soil. It was also important to evaluate the resistance of Festulolium braunii in comparison to Lolium perenne to different weather conditions and the influence of this hybrid on the quantity and quality of meadow sward yields.

\section{Materials and Methods}

\subsection{Location and Soil Conditions of Study Objects}

The study was carried out on grasslands located on organic soil of peat-muck soil type, subtype - mucky soil in the Randow river valley, near the vicinity of Ramin (Germany), (Figure 1).

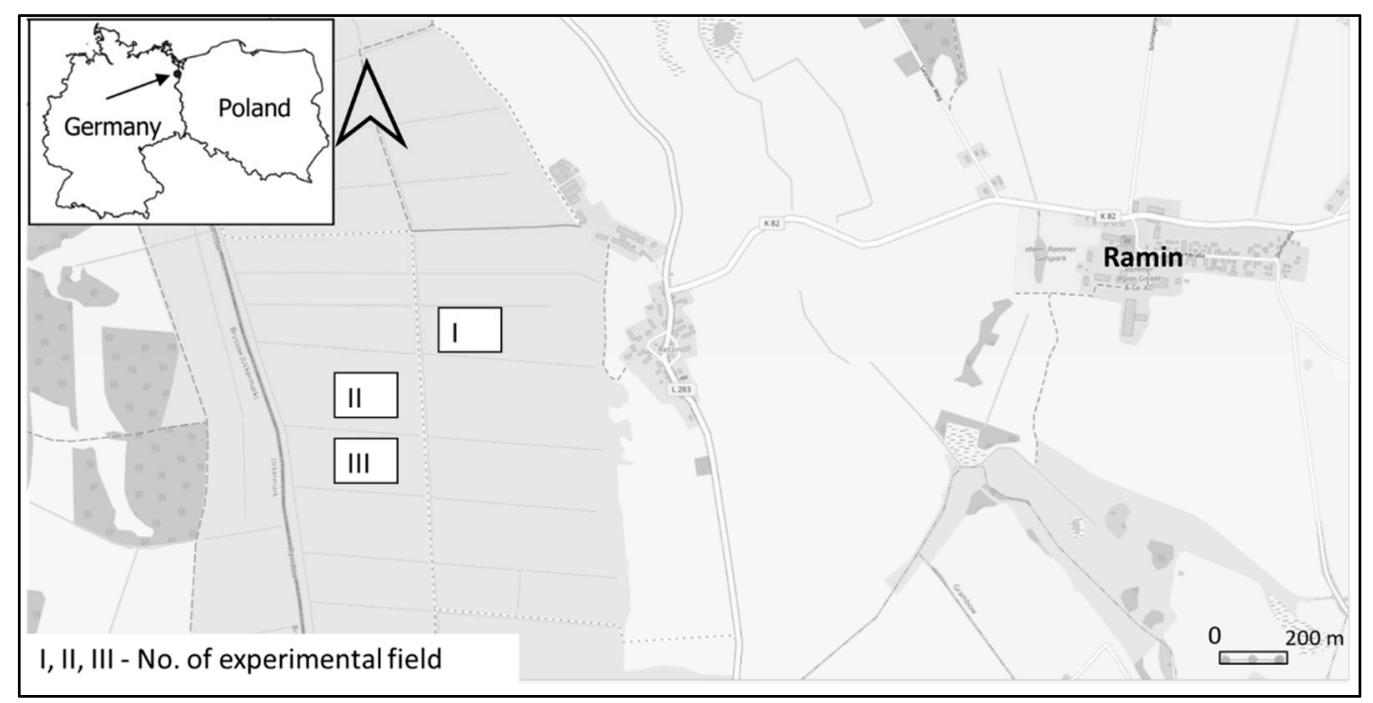

Figure 1. Location of field experiments, geographic coordinates: I-14.252689, 53.409775; II14.245987, 53.408330; III-14.246842, 53.405511. 
The Randow river valley is filled with fluviogenic peatland, which was sanded in the past. The surface layer of $30-50 \mathrm{~cm}$ is made up of mineral-organic material (post-glacial sand with gravel mixed with muck). The formed mineral-organic layer has features typical for mucky soils. The thickness of the peat bog ranges from $90 \mathrm{~cm}$ to $220 \mathrm{~cm}$. The grassland belongs to a farm: Raminer Agrar GmbH\&Co (Ramin, Mecklenburg-Vorpommern, Germany).

\subsection{Meteorological Conditions during the Study Period}

According to Grzegorczyk [12], the sum of precipitation and temperature distribution are among the most important factors modifying the development of plants and their yield. Meteorological data from weather station in Löcknitz (Germany) for the years 2009-2018 and in the multi-year 1980-2018 (Table 1) indicate large differences in air temperature and sum of precipitation during the study. The average air temperature and precipitation during the whole vegetation period in the years of the study were higher than in the corresponding multi-year period. In the study years, the year 2018 with the average temperature in the vegetation period (IV-X) of $17.2^{\circ} \mathrm{C}$ was the warmest, and the years 2013 and 2014 were also warm with the average air temperature of 16.4 and $16.7{ }^{\circ} \mathrm{C}$, respectively, in the plant growth period (Table 1). The average values for the vegetation period as well as for the whole year exceeded the multi-year average value by more than $3^{\circ} \mathrm{C}$. The months with high air temperature in 2009 were July and August, where the average temperature was 19.4 and $19.6^{\circ} \mathrm{C}$ respectively; in 2010 was July; in 2011 was August; in 2013 were June and July; in 2014 a period July-September; in 2016 a period in May-September; and in 2017 a period July-August. In the warmest year 2018, the high average air temperature was from May to the end of September, where the average temperatures were much higher than the averages for the same period in the 1980-2018 multi-year (Table 1).

Table 1. The average monthly air temperature $\left({ }^{\circ} \mathrm{C}\right)$ and monthly sum of precipitation $(\mathrm{mm})$.

\begin{tabular}{|c|c|c|c|c|c|c|c|c|c|c|c|c|c|c|}
\hline \multirow{2}{*}{ Year } & \multicolumn{14}{|c|}{ Month } \\
\hline & I & II & III & IV & $\mathbf{V}$ & VI & VII & VIII & IX & $X$ & XI & XII & I-XII & IV-X \\
\hline \multicolumn{15}{|c|}{ Temperature $\left[{ }^{\circ} \mathrm{C}\right]$} \\
\hline The multi-year mean & -1.1 & -0.3 & 2.8 & 7.4 & 12.7 & 16.0 & 17.6 & 17.2 & 13.3 & 8.8 & 3.8 & 0.4 & 8.2 & 13.3 \\
\hline 2009 & -3.1 & 1.5 & -3.9 & 12.3 & 13.4 & 15.4 & 19.4 & 19.6 & 14.7 & 7.8 & 6.7 & -0.2 & 8.6 & 14.7 \\
\hline 2010 & -5.5 & -0.6 & 3.8 & 8.7 & 11.1 & 17.0 & 22.2 & 18.5 & 13.2 & 7.5 & 4.7 & -4.7 & 8.0 & 14.0 \\
\hline 2011 & 0.7 & -0.9 & 3.9 & 11.9 & 14.3 & 18.2 & 17.7 & 18.3 & 14.9 & 9.5 & 4.1 & 3.9 & 9.7 & 15.0 \\
\hline 2012 & 1.5 & -2.3 & 6.3 & 8.8 & 15.5 & 16.2 & 18.6 & 18.1 & 14.5 & 8.7 & 5.1 & -0.7 & 9.2 & 14.3 \\
\hline 2013 & -3.5 & 4.0 & 3.5 & 11.4 & 17.5 & 20.3 & 21.2 & 18.5 & 14.8 & 11.1 & 5.2 & 3.0 & 10.6 & 16.4 \\
\hline 2014 & -0.5 & 1.7 & 6.4 & 11.1 & 14.0 & 16.9 & 21.8 & 21.5 & 20.2 & 11.1 & 6.2 & 2.0 & 11.0 & 16.7 \\
\hline 2015 & 1.1 & 0.0 & 3.9 & 9.7 & 11.9 & 14.5 & 17.6 & 20.1 & 13.0 & 7.3 & 5.6 & 5.3 & 9.2 & 13.4 \\
\hline 2016 & -1.2 & 3.2 & 4.2 & 8.9 & 16.9 & 19.2 & 19.4 & 18.2 & 17.1 & 8.8 & 3.9 & 2.7 & 10.1 & 15.5 \\
\hline 2017 & -0.1 & 1.2 & 6.2 & 8.0 & 14.7 & 18.5 & 18.5 & 19.4 & 14.2 & 11.4 & 6.2 & 3.4 & 10.1 & 15.0 \\
\hline 2018 & 2.5 & 0.4 & 2.6 & 13.0 & 18.6 & 20.7 & 20.4 & 18.8 & 18.4 & 10.7 & 5.7 & 3.9 & 11.3 & 17.2 \\
\hline \multicolumn{15}{|c|}{ Precipitation [mm] } \\
\hline The multi-year sum & 35.0 & 26.0 & 34.0 & 38.0 & 52.0 & 62.0 & 67.0 & 54.0 & 47.0 & 39.0 & 41.0 & 41.0 & 559.2 & 359.0 \\
\hline 2009 & 24.7 & 15.1 & 21 & 16.6 & 70.3 & 60.7 & 61.9 & 58.0 & 45.4 & 82.7 & 46.9 & 32.7 & 475.2 & 395.6 \\
\hline 2010 & 43.2 & 27.7 & 34.7 & 27.0 & 70.5 & 62.4 & 70.5 & 159.2 & 55.5 & 21.6 & 49.1 & 33.6 & 655.0 & 466.8 \\
\hline 2011 & 26.3 & 24.5 & 27.3 & 19.7 & 63.4 & 101.2 & 211.0 & 58.5 & 61.2 & 29.6 & 93.4 & 80.5 & 796.6 & 544.6 \\
\hline 2012 & 52.4 & 29.7 & 12.6 & 41.0 & 9.3 & 58.4 & 89.3 & 72.5 & 60.3 & 39.6 & 42.5 & 44.4 & 552.0 & 371.5 \\
\hline 2013 & 59.0 & 24.0 & 14.0 & 16.0 & 68.0 & 101.0 & 27.0 & 40.0 & 43.0 & 47.0 & 39.0 & 36.0 & 514.0 & 343.8 \\
\hline 2014 & 39.9 & 15.2 & 24.9 & 42.8 & 61.1 & 43.1 & 34.6 & 70.6 & 74.9 & 53.1 & 19.0 & 54.8 & 534.0 & 339.3 \\
\hline 2015 & 57.0 & 1.5 & 36.5 & 15.5 & 62.0 & 36.0 & 68.5 & 49.5 & 31.0 & 43.0 & 46.5 & 3.0 & 450.0 & 283.6 \\
\hline 2016 & 32.6 & 34.5 & 25.7 & 25.7 & 43.7 & 70.6 & 68.7 & 41.2 & 9.7 & 45.1 & 50.5 & 25.7 & 473.7 & 304.7 \\
\hline 2017 & 25.4 & 38.1 & 39.6 & 38.8 & 91.8 & 116.7 & 180.3 & 76.2 & 23.8 & 87.0 & 67.8 & 46.9 & 832.4 & 614.6 \\
\hline 2018 & 66.5 & 6.7 & 39.1 & 29.1 & 38.5 & 24.8 & 117.2 & 12.9 & 14.7 & 16.2 & 5.9 & 70.0 & 441.6 & 253.4 \\
\hline
\end{tabular}

In all the years of the study a much higher sum of precipitation than in multi-year period was recorded in 2017, 2011 and 2010 (Table 1). The sum of precipitation in those 
years for the months of the vegetation period (IV-X) significantly exceeded the amounts observed in the same period of time in multi-year period on average by about 256, 186 and $111 \mathrm{~mm}$, respectively. The highest amount of precipitation was recorded in July both in 2011 and 2017 and 2018 (211.0, 180.3 and $117.2 \mathrm{~mm})$. In the remaining years, the amount of precipitation in the vegetation period was similar to those recorded for the multi-year period. In the wettest year 2017 the highest sum of precipitation was recorded in the months from May to August, in which the precipitation exceeded the sum of the multi-year period by $230 \mathrm{~mm}$. In the analysed period there was much less rainfall in April than in many years. The rainfall in this month is important for the yield of the first swath.

\subsection{Characteristics of Field Experiments}

Grassland renewal was carried out using the full cultivation (tillage) method (the existing grassland was eliminated and seeds of a new grass mix were sown). The results presented in this paper relate to three single-factor experiments from the vegetation seasons 2009-2011, 2012-2013 and 2013-2018. The meadow experiments were established using the method of random blocks in four repetitions (Table 2). The area of a single plot was $10 \mathrm{~m}^{2}$. The following grass species were used for grassland renewal: Festulolium braunii, Lolium perenne, Poa pratensis, Phleum pratense, Dactylis glomerata. The composition of grass mixtures used for sowing individual objects of the experiment is presented in Table 3.

Table 2. Schematic of the distribution of test sites in the field experiments.

\begin{tabular}{|c|c|c|c|}
\hline \multicolumn{4}{|c|}{ Repetition } \\
\hline A & B & $\mathrm{C}$ & $\mathrm{D}$ \\
\hline \multicolumn{4}{|c|}{ Field experiment I (2009-2011) } \\
\hline 3 & 4 & 5 & 6 \\
\hline 4 & 1 & 3 & 3 \\
\hline 5 & 6 & 1 & 2 \\
\hline 6 & 2 & 4 & 1 \\
\hline 1 & 5 & 2 & 4 \\
\hline 2 & 3 & 6 & 5 \\
\hline \multicolumn{4}{|c|}{ Field experiment II (2012-2013) } \\
\hline 3 & 1 & 5 & 6 \\
\hline 6 & 4 & 3 & 2 \\
\hline 5 & 6 & 1 & 4 \\
\hline 4 & 2 & 6 & 1 \\
\hline 1 & 5 & 2 & 3 \\
\hline 2 & 3 & 4 & 5 \\
\hline \multicolumn{4}{|c|}{ Field experiment III (2012-2018) } \\
\hline 3 & 1 & 2 & 3 \\
\hline 2 & 3 & 1 & 2 \\
\hline 1 & 2 & 3 & 1 \\
\hline
\end{tabular}

The pratotechnical treatments carried out in the experiment included: leveling, rolling, fertilizing and mowing. During the spring leveling and rolling, a multi-component fertilizer was applied-NPK (Mg S) 5-16-24 (4-7), in which $15 \mathrm{~kg} \mathrm{~N}, 21 \mathrm{~kg} \mathrm{P,} 60 \mathrm{~kg} \mathrm{~K}, 7 \mathrm{~kg} \mathrm{Mg}$ and $21 \mathrm{~kg} \mathrm{~S}$ per 1 ha was applied into the soil. Additionally, $72 \mathrm{~kg} \cdot \mathrm{ha}^{-1} \mathrm{~N}$ in the form of ammonium nitrate and urea solution (AHL) was used. Nitrogen in the form of AHL in the dose of $65 \mathrm{~kg} \cdot \mathrm{ha}^{-1} \mathrm{~N}$ was applied before the 2nd swath, and $36 \mathrm{~kg} \cdot \mathrm{ha}^{-1} \mathrm{~N}$, also in the form of AHL, before the third swath.

The three to five swaths were collected in the vegetation seasons. The meadow sward of the first swath was harvested at the stage of booting/inflorescence emergence (beginning of heading) of the dominant species, and subsequent swaths at intervals from four to seven weeks also at the stage of booting/inflorescence emergence (beginning of heading). The biomass collected from the analyzed grasslands was used for hay silage. Detailed research included: floristic composition of meadow sward, yields of fresh and dry matter (DM) 
and content of organic components (crude protein, crude fiber, water-soluble sugars) and the energy value-NEL (net energy lactation). The energy value was made according to method of Pries et al. [56]. The content of protein and soluble sugars was determined by the NIRS method [PN-EN ISO 12099. 2013]. Samples of plant material were taken from each plot of $1 \mathrm{~m}^{2}$. The floristic composition of the sward was determined using the botanicalweighted method [57], and the study gives the floristic composition of the first swath (the most representative for each year of study). Chemical analyses in cooperation with the National Research Institute for Agriculture and Fisheries of Mecklenburg-Vorpommern (Landesforschungsanstalt für Landwirtschaft und Fischerei MV) in Dummerstorf were carried out in the accredited laboratory of VDLUFA Rostock.

Table 3. Proportion of seeds of species in mixtures in $\%$ by weight in relation to the seeding standard of the species.

\begin{tabular}{llcccccc}
\hline \multirow{2}{*}{ Experiment } & Species & \multicolumn{7}{c}{ Mixture (Object) } & $\mathbf{1}$ \\
\cline { 2 - 7 } & & $\mathbf{1}$ & $\mathbf{2}$ & $\mathbf{3}$ & $\mathbf{4}$ & $\mathbf{5}$ & $\mathbf{6}$ \\
\hline & Festulolium braunii & 50 & 43 & 42 & 30 & 21 & 21 \\
& Lolium perenne & 50 & 28 & 29 & 20 & 29 & 50 \\
I-(2009-2011) & Poa pratensis & - & 29 & 11 & 10 & 11 & 11 \\
& Phleum pratense & - & - & 18 & 0 & 18 & 18 \\
& Dactylis glomerata & - & - & - & 40 & 21 & - \\
& Festulolium braunii & 50 & 43 & 42 & 21 & 21 & 30 \\
& Lolium perenne & 50 & 28 & 29 & 50 & 29 & 20 \\
II-(2012-2013) & Poa pratensis & - & 29 & 11 & 11 & 11 & 10 \\
& Phleum pratense & - & - & 18 & 18 & 18 & - \\
& Dactylis glomerata & - & - & - & - & 21 & 40 \\
& Festulolium braunii & 50 & 34 & 35 & & & \\
& Lolium perenne & 50 & 66 & 20 & & & \\
& Phleum pratense & - & - & 20 & & & \\
& Festuca arundinacea & - & - & 25 & & & \\
\hline
\end{tabular}

${ }^{1}$ The percentage share of a given species in the mixture were calculated in relation to the seeding of this species in a pure sowing.

\subsection{Statistical Analysis}

The results of the study showing the dry matter yield development were statistically analyzed using the analysis of variance (ANOVA) procedure and the differences were tested with the Tukey test at the significance level $p \leq 0.05$. Multivariate analysis was performed by applying principal component analysis (PCA). PCA transforms the data to a new coordinate system, retaining most of the information (the greatest variance by scalar projection of the data comes to lie on the first coordinate, the second greatest variance on the second coordinate-the so-called principal components). The analysis of the influence of mixtures with different floristic composition on the yield quality of meadow sward was also carried out. In order to determine the relation between mixtures and quality of meadow sward (content of crude protein, water-soluble carbohydrates, fibre and obtained dry matter), the results obtained were subjected to comparative analysis. The obtained results were subjected to agglomerative cluster analysis and classified into groups in a hierarchical arrangement by Ward's method. The method uses analysis of variance to estimate the distance between clusters [58]. The data were auto-scaled during pre-processing. All statistical analyses were performed using Statistica 12.5 (StatSoft Polska, Cracow, Poland).

\section{Results and Discussion}

\subsection{Floristic Composition of Meadow Sward}

The floristic composition of meadow sward in 2009, 2012 and 2013 after grassland renewal coincided with the participation of individual species in mixtures (Tables 4-6). 
Table 4. Floristic composition of meadow sward (\%) of experiment I from first cut in the years of research (2009-2011).

\begin{tabular}{|c|c|c|c|c|c|}
\hline \multirow{2}{*}{ Object * } & \multirow{2}{*}{ Species } & \multirow{2}{*}{ Share in the Mixture Prepared for Sowing (\%) } & \multicolumn{3}{|c|}{ Share in Sward $(\%)$ in Years } \\
\hline & & & 2009 & 2010 & 2011 \\
\hline \multirow{4}{*}{1} & Festulolium braunii & 50 & 59.0 & 66.0 & 62.1 \\
\hline & Lolium perenne & 50 & 41.0 & 2.6 & 4.1 \\
\hline & Poa pratensis & - & - & 18.2 & 22.2 \\
\hline & Others & - & - & 13.0 & 11.6 \\
\hline \multirow{4}{*}{2} & Festulolium braunii & 43 & 31.0 & 56.6 & 52.8 \\
\hline & Lolium perenne & 28 & 48.5 & 3.7 & 4.2 \\
\hline & Poa pratensis & 29 & 20.5 & 30.5 & 24.0 \\
\hline & Others & - & - & 9.2 & 19.0 \\
\hline \multirow{5}{*}{3} & Festulolium braunii & 42 & 35.0 & 79.5 & 43.7 \\
\hline & Lolium perenne & 29 & 21.5 & 0.3 & 2.0 \\
\hline & Poa pratensis & 11 & 33.5 & 9.9 & 14.5 \\
\hline & Phleum pratense & 18 & 10.0 & 10.3 & 16.4 \\
\hline & Others & - & - & - & 23.4 \\
\hline \multirow{5}{*}{4} & Festulolium braunii & 30 & 34.5 & 28.7 & 36.1 \\
\hline & Lolium perenne & 20 & 33.0 & 1.3 & 3.5 \\
\hline & Poa pratensis & 10 & 14.5 & 2.2 & 17.6 \\
\hline & Dactylis glomerata & 40 & 18.0 & 67.8 & 25.6 \\
\hline & Others & - & - & - & 17.1 \\
\hline \multirow{6}{*}{5} & Festulolium braunii & 21 & 33.5 & 39.8 & 29.9 \\
\hline & Lolium perenne & 29 & 29.0 & 5.1 & 4.2 \\
\hline & Poa pratensis & 11 & 14.5 & 9.5 & 16.8 \\
\hline & Phleum pratense & 18 & 7.5 & 18.8 & 24.2 \\
\hline & Dactylis glomerata & 21 & 15.5 & 26.8 & 19.5 \\
\hline & Others & - & - & - & 5.4 \\
\hline \multirow{5}{*}{6} & Festulolium braunii & 21 & 38.5 & 34.8 & 45.4 \\
\hline & Lolium perenne & 50 & 29.0 & 2.2 & 3.8 \\
\hline & Poa pratensis & 11 & 20.5 & 32.3 & 21.6 \\
\hline & Phleum pratense & 18 & 12.0 & 26.6 & 20.2 \\
\hline & Others & - & - & 4.0 & 9.0 \\
\hline
\end{tabular}

* Explanations: objects identical with mixtures, whose composition is given in Table 3.

Table 5. Floristic composition of meadow sward (\%) of experiment II from first cut in the years of research (2012-2013).

\begin{tabular}{|c|c|c|c|c|}
\hline \multirow{2}{*}{ Object * } & \multirow{2}{*}{ Species } & \multirow{2}{*}{ Share in the Mixture Prepared for Sowing (\%) } & \multicolumn{2}{|c|}{ Share in Sward $(\%)$ in Years } \\
\hline & & & 2012 & 2013 \\
\hline \multirow{3}{*}{1} & Festulolium braunii & 50 & 70.5 & 67.5 \\
\hline & Lolium perenne & 50 & 29.0 & 32.0 \\
\hline & Others & - & 0.5 & 0.5 \\
\hline \multirow{4}{*}{2} & Festulolium braunii & 43 & 67.0 & 54.0 \\
\hline & Lolium perenne & 28 & 22.0 & 26.0 \\
\hline & Poa pratensis & 29 & 7.0 & 16.0 \\
\hline & Others & - & 4.0 & 4.0 \\
\hline \multirow{5}{*}{3} & Festulolium braunii & 42 & 49.0 & 49.0 \\
\hline & Lolium perenne & 29 & 24.0 & 25.0 \\
\hline & Poa pratensis & 11 & 5.0 & 9.0 \\
\hline & Phleum pratense & 18 & 22.0 & 17.0 \\
\hline & Others & - & - & - \\
\hline \multirow{5}{*}{4} & Festulolium braunii & 21 & 24.0 & 24.0 \\
\hline & Lolium perenne & 50 & 48.0 & 49.0 \\
\hline & Poa pratensis & 11 & 7.0 & 12.0 \\
\hline & Phleum pratense & 18 & 19.0 & 14.0 \\
\hline & Others & - & 2.0 & 1.0 \\
\hline \multirow{6}{*}{5} & Festulolium braunii & 21 & 20.0 & 30.0 \\
\hline & Lolium perenne & 29 & 36.0 & 23.0 \\
\hline & Poa pratensis & 11 & 6.0 & 14.0 \\
\hline & Phleum pratense & 18 & 21.0 & 10.0 \\
\hline & Dactylis glomerata & 21 & 16.0 & 22.0 \\
\hline & Others & - & 1.0 & 1.0 \\
\hline \multirow{5}{*}{6} & Festulolium braunii & 30 & 42.0 & 49.0 \\
\hline & Lolium perenne & 20 & 23.0 & 23.0 \\
\hline & Poa pratensis & 10 & 7.0 & 8.0 \\
\hline & Dactylis glomerata & 40 & 26.0 & 17.0 \\
\hline & Others & - & 2.0 & 1.0 \\
\hline
\end{tabular}

* Explanations: objects identical with mixtures, whose composition is given in Table 3. 
Table 6. Floristic composition of meadow sward (\%) of experiment III from first cut in the years of research (2013-2018).

\begin{tabular}{|c|c|c|c|c|c|c|c|c|}
\hline \multirow{2}{*}{ Object * } & \multirow{2}{*}{ Species } & \multirow{2}{*}{ Share in the Mixture Prepared for Sowing (\%) } & \multicolumn{6}{|c|}{ Share in Sward (\%) in Years } \\
\hline & & & 2013 & 2014 & 2015 & 2016 & 2017 & 2018 \\
\hline \multirow{4}{*}{1} & Festulolium braunii & 50 & 62.0 & 75.0 & 71.0 & 74.0 & 81.0 & 62.0 \\
\hline & Lolium perenne & 50 & 38.0 & 25.0 & 26.0 & 11.0 & 11.0 & 19.0 \\
\hline & Others & - & - & - & 3.0 & 15.0 & 8.0 & 19.0 \\
\hline & Festulolium braunii & 34 & 37.0 & 52.0 & 37.0 & 75.0 & 68.0 & 51.0 \\
\hline \multirow[t]{4}{*}{2} & Lolium perenne & 66 & 63.0 & 48.0 & 60.0 & 18.0 & 27.0 & 31.0 \\
\hline & Others & - & - & - & 3.0 & 7.0 & 5.0 & 18.0 \\
\hline & Festulolium braunii & 35 & 42.0 & 44.0 & 44.0 & 24.0 & 25.0 & 22.0 \\
\hline & Lolium perenne & 20 & 26.0 & 22.0 & 21.0 & 14.0 & 16.0 & 12.0 \\
\hline \multirow[t]{3}{*}{3} & Phleum pratense & 20 & 12.0 & 8.0 & 10.0 & 9.0 & 6.0 & 9.0 \\
\hline & Festuca arundinacea & 25 & 20.0 & 26.0 & 23.0 & 46.0 & 48.0 & 42.0 \\
\hline & Others & - & - & - & 2.0 & 7.0 & 5.0 & 15.0 \\
\hline
\end{tabular}

* Explanations: objects identical with mixtures, whose composition is given in Table 3.

The paper presents results concerning floristic composition only from the first swath, because in the remaining swaths they were similar. A mild winter with a period of a short strong frost and surface flooding in the spring of 2010-2011 caused Lolium perenne to decline as a percentage of the floristic composition (Table 4).

Analyzing the mixture on object 1, where the share of Lolium perenne in 2009 was $41.0 \%$, it decreased to $2.6 \%$ in 2010 and its share in 2011 was $4.1 \%$. The place of Lolium perenne in this series of the experiment was taken by: Festulolium braunii, Poa pratensis, Dactylis glomerata and Phleum pratense. Frost resistance of Festulolium braunii is indicated by studies by Thomas and Humphreys [36], Humphreys et al. [59], Yamada et al. [46], Touno et al. [47], Šimkūnas et al. [60], Sosnowski [44], Østrem et al. [38] and excessive soil moisture by Matoba et al. [45] and Touno [61].

A similar arrangement of results concerned all the evaluated mixtures, of which the most stable floristic composition was noted in the case of multi-species mixtures with a low proportion of Lolium perenne, i.e., mixtures from 2 to 5 . Grass species introduced as components of the aforementioned mixtures showed high resistance to the existing habitat conditions and stability in the floristic composition in particular years (Table 4).

In the years of more stable weather conditions (2012 and 2013), the composition of mixtures tested in the second experiment proved to be more stable and close to the assumed sowing standard (Table 5).

In the third experiment, which lasted much longer than the second experiment, with a diverse set of weather conditions (amount and distribution of precipitation, very low temperatures in spring 2016) the floristic composition of the sward was stable in the first three years of the study. On the other hand, in the meadow sward of the first swath of 2016, freezing of plants, especially Lolium perenne and partly also Festulolium braunii, was observed, due to short-lived very low temperatures that occurred in early spring. This was not observed in Festuca arundinacea and Phleum pratense, which was reflected in the appearance of meadow sward on individual plots and its floristic composition (Table 6). Higher resistance to low temperatures of Festulolium braunii than Lolium multiflorum but lower than Festuca pratensis is indicated by the study of Šimkūnas et al. [60].

The process of sward regeneration with the participation of Lolium perenne and Festulolium braunii plants lasted until mid-June, because the floristic composition found during the harvest of the second swath (9 June 2016) was repeated in subsequent swaths. The results of all experiments showed that Festulolium braunii plants have a high stability of in sward and a lower response to unfavorable weather conditions compared to Lolium perenne and are slightly inferior to species such as Festuca arundinacea and Phleum pratense, which are reported in the literature as persistent species and well-developing in terms of habitat on organic soils [12,33]. 
PCA analysis showed that abundance in the Festulolium braunii and Lolium perenne sward depended on precipitation in February, March, April, May and June, during the growing season and throughout the year, as well as on temperature in March, April, July and August. The presented climatic conditions in the studied decade had a different effect on the abundance in the sward of Festulolium braunii and Lolium perenne (Figure 2). The PCA analysis should be treated with caution because it did not consider short winter and early spring frosts and surface water flooding, which affected Festulolium braunii and Lolium perenne cover. Nevertheless, this analysis and the results of $\mathrm{Fb}$ and Lp coverage obtained clearly indicate that Festulolium braunii is more durable in the sward than Lolium perenne under varying weather conditions.

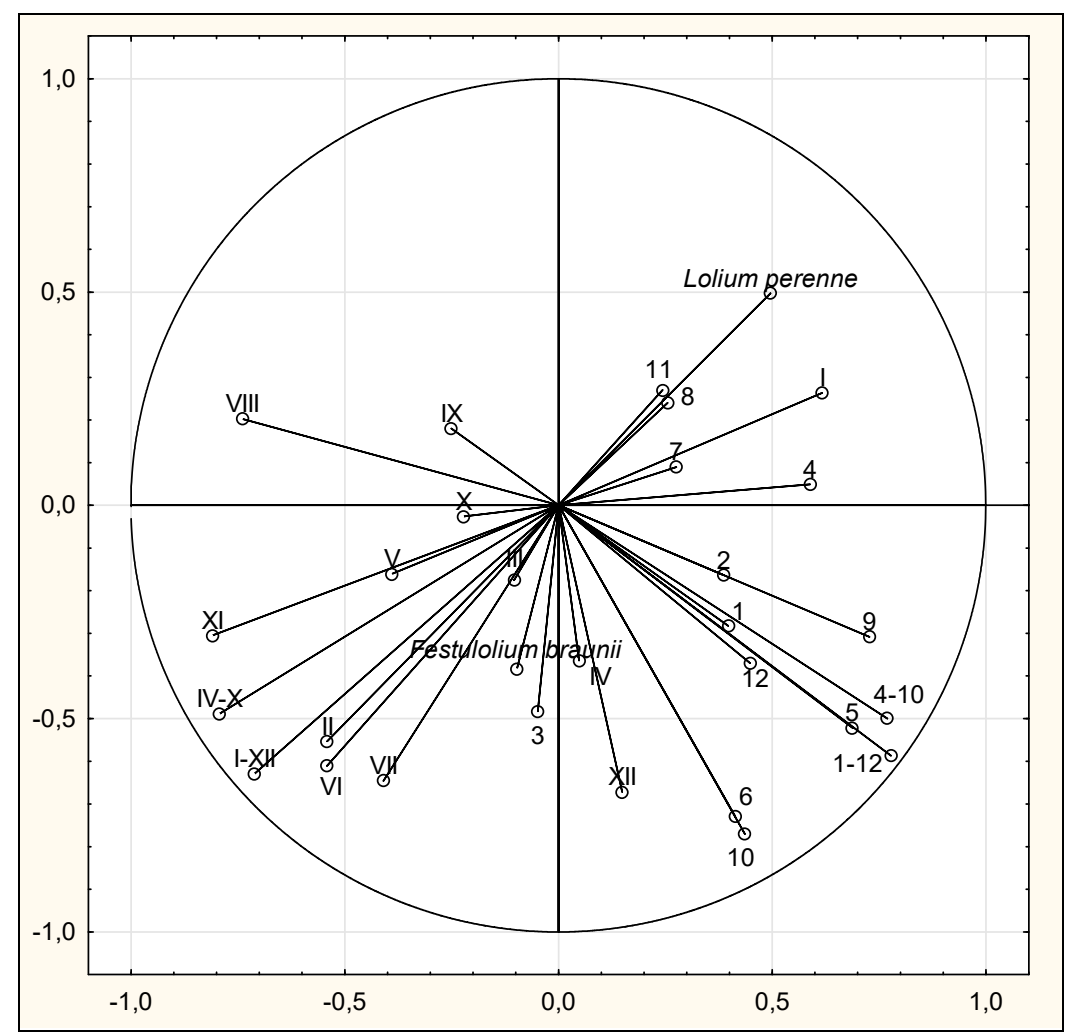

Figure 2. The principal component analysis (PCA) for Lolium perenne, Festulolium braunii abundance and weather conditions. Festulolium braunii-abundance in the sward, Lolium perenne-abundance in the swards. I-XII-rainfall ( $\mathrm{mm}$ ) in individual months. 1-12-air temperature in individual months.

The high persistence of Festulolium braunii in the habitat even under unfavorable weather conditions is due to its well-developed root system, which it inherited from meadow fescue $[36,41,42,55,62,63]$.

Lolim perenne is a very valuable grass of high fodder value willingly eaten by cattle. It is the main component of grassland sward in Europe [64]. This grass is durable and expansive but not very tolerant of adverse environmental conditions [37]. Kulik and Baryła [65], sowing a mixture of composition: Lolium perenne-35\%, Trifolium repens$35 \%$, Dactylis glomerata-10\% and Phleum pratense-20\% on organic soil, after previously applying Roundup herbicide and biting and rolling, found high persistence of Lolium perenne in pasture sward. After 12 years, the share of this species in the sward averaged $19.9 \%$ in the first regrowth and $22.0 \%$ in the third regrowth. These authors found large changes in the share of Lolium perenne in particular years, which was related to habitat conditions, especially water and thermal conditions. They found the loss of perennial ryegrass in frosty winters and its regeneration in the years when it increased its share in pasture sward. In general, during 12 years with favorable weather conditions, the fluctuations of Lolium perenne share in the pasture sward ranged from $7.3 \%$ to $63.0 \%$. 
Such an arrangement of results is confirmed by our study, in which in conditions of low temperatures during winter and excess water in spring, there was a significant decrease in the share of Lolium perenne. The fast regeneration of Lolium perenne, as indicated by the quoted authors, was not confirmed in our study, as the lower share of this species found in 2010 was maintained in the next year 2011. The high expansiveness of Poa pratensis in the period less favorable for Lolium perenne, which was indicated in peat-muck soils Kamiński [33], Baryła and Drozd [66] and Kulik and Baryła [65] was confirmed in our study. High prevalence of Poa pratensis on organic and organic-mineral soils of Western Pomerania in Poland was found by Czyż et al. $[67,68]$.

\subsection{Dry Matter Yield}

Biomass obtained from objects sown with particular mixtures with different share of Festulolium braunii in the sward was characterized by a similar dry matter content, therefore in this study it was limited only to dry matter yields (Tables 7 and 8). In the first experiment carried out in the years 2009-2011, the highest dry matter yield was obtained on object 5 (13.85 tha ${ }^{-1}$ average from years), where the sward was a multi-species mixture with following composition: Festulolium braunii (39.5-29.9\%), Lolium perenne, Poa pratensis, Dactylis glomerata and Phleum pratense. The yields obtained were higher than the other mixtures with a similar share of this species in mixtures 4 and 6 by $9.6 \%$ on average and with a higher share of Festulolium braunii in the sward in mixtures $1-3$ by $12.3 \%$ on average (Table 6).

Table 7. Dry matter (DM) yield in $\mathrm{t} \cdot \mathrm{ha}^{-1}$ from experiments I and II.

\begin{tabular}{|c|c|c|c|c|c|c|c|c|c|}
\hline \multirow{2}{*}{ Year } & \multirow{2}{*}{ Swath } & \multicolumn{6}{|c|}{ Mixture (Object) } & \multirow{2}{*}{ Mean } & \multirow{2}{*}{$\operatorname{LSD}_{0.05}{ }^{1}$} \\
\hline & & 1 & 2 & 3 & 4 & 5 & 6 & & \\
\hline \multicolumn{10}{|c|}{ Experiment I } \\
\hline & 1 & 2.73 & 3.10 & 2.61 & 2.87 & 2.90 & 2.65 & 2.81 & \multirow{5}{*}{0.76} \\
\hline \multirow{4}{*}{2009} & 2 & 3.33 & 3.07 & 2.89 & 3.11 & 3.60 & 3.68 & 3.28 & \\
\hline & 3 & 3.36 & 3.05 & 2.73 & 3.13 & 3.63 & 3.32 & 3.20 & \\
\hline & 4 & 2.17 & 2.06 & 2.29 & 1.77 & 2.13 & 2.09 & 2.09 & \\
\hline & Total & 11.59 & 11.28 & 10.52 & 10.88 & 12.26 & 11.74 & 11.38 & \\
\hline \multirow{4}{*}{2010} & 1 & 3.70 & 1.95 & 4.95 & 3.96 & 5.50 & 2.43 & 3.75 & \multirow{4}{*}{0.61} \\
\hline & 2 & 3.95 & 3.82 & 5.01 & 5.29 & 4.39 & 3.96 & 4.40 & \\
\hline & 3 & 2.57 & 2.04 & 1.53 & 1.56 & 2.09 & 1.88 & 1.94 & \\
\hline & Total & 10.22 & 7.81 & 11.49 & 10.81 & 11.98 & 8.27 & 10.09 & \\
\hline \multirow{4}{*}{2011} & 1 & 4.14 & 3.65 & 4.53 & 4.14 & 4.68 & 4.25 & 4.23 & \multirow{4}{*}{1.12} \\
\hline & 2 & 4.79 & 4.68 & 3.95 & 4.87 & 5.53 & 5.20 & 4.84 & \\
\hline & 3 & 6.38 & 6.77 & 7.55 & 8.03 & 7.09 & 6.90 & 7.12 & \\
\hline & Total & 15.31 & 15.10 & 16.03 & 17.04 & 17.30 & 16.35 & 16.19 & \\
\hline \multirow[t]{2}{*}{ Mean of years } & \multirow{2}{*}{\multicolumn{8}{|c|}{ 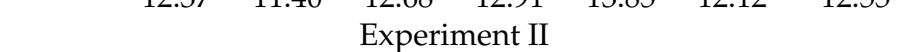 }} & 0.71 \\
\hline & & & & & & & & & \\
\hline \multirow{4}{*}{2012} & 1 & 3.12 & 3.34 & 3.67 & 3.56 & 4.00 & 3.96 & 3.61 & \multirow{4}{*}{0.62} \\
\hline & 2 & 5.59 & 5.29 & 4.99 & 5.93 & 4.90 & 5.02 & 5.29 & \\
\hline & 3 & 5.78 & 5.49 & 5.85 & 5.97 & 6.01 & 6.22 & 5.89 & \\
\hline & Total & 14.49 & 14.12 & 14.51 & 15.46 & 14.91 & 15.20 & 14.78 & \\
\hline \multirow{5}{*}{2013} & 1 & 4.29 & 4.79 & 4.96 & 4.24 & 4.42 & 5.10 & 4.63 & \multirow{5}{*}{1.02} \\
\hline & 2 & 2.49 & 2.56 & 2.38 & 2.71 & 2.49 & 2.81 & 2.57 & \\
\hline & 3 & 5.71 & 5.97 & 6.42 & 5.89 & 6.23 & 6.09 & 6.05 & \\
\hline & 4 & 1.98 & 2.12 & 2.34 & 2.26 & 2.15 & 2.08 & 2.16 & \\
\hline & Total & 14.47 & 15.44 & 16.10 & 15.10 & 15.29 & 16.08 & 15.41 & \\
\hline Mean of years & & 14.48 & 14.78 & 15.31 & 15.28 & 15.10 & 15.64 & 15.10 & n.s. \\
\hline
\end{tabular}

${ }^{1}$ n.s.-not significant. 
Table 8. Dry matter yield in $\mathrm{t} \cdot \mathrm{ha}^{-1}$ from experiment III.

\begin{tabular}{|c|c|c|c|c|c|c|c|c|}
\hline \multirow{2}{*}{ Mixture } & \multirow{2}{*}{ Swath } & \multicolumn{6}{|c|}{ Year } & \multirow{2}{*}{ Mean } \\
\hline & & 2013 & 2014 & 2015 & 2016 & 2017 & 2018 & \\
\hline \multirow{6}{*}{1} & 1 & 3.01 & 6.16 & 3.18 & 1.21 & 3.90 & 2.44 & 3.30 \\
\hline & 2 & 3.98 & 3.50 & 3.29 & 2.88 & 2.50 & 1.93 & 3.10 \\
\hline & 3 & 5.29 & 4.22 & 4.02 & 5.40 & 4.90 & 2.82 & 4.44 \\
\hline & 4 & 4.50 & 3.98 & 3.02 & 2.82 & - & 2.43 & 2.94 \\
\hline & 5 & - & 2.48 & 3.68 & 3.20 & - & - & 1.34 \\
\hline & Total & 16.78 & 20.34 & 17.19 & 15.51 & 11.30 & 9.62 & 15.12 \\
\hline \multirow{6}{*}{2} & 1 & 4.31 & 6.23 & 3.15 & 0.86 & 3.35 & 3.54 & 3.53 \\
\hline & 2 & 4.09 & 3.38 & 3.12 & 2.77 & 2.42 & 1.82 & 3.11 \\
\hline & 3 & 5.34 & 3.89 & 4.13 & 5.51 & 4.02 & 3.00 & 4.40 \\
\hline & 4 & 3.59 & 3.39 & 2.89 & 2.76 & - & 2.10 & 2.59 \\
\hline & 5 & - & 2.23 & 3.44 & 2.97 & - & - & 1.23 \\
\hline & Total & 17.33 & 19.12 & 16.73 & 14.87 & 9.79 & 10.46 & 14.86 \\
\hline \multirow{5}{*}{3} & 1 & 3.28 & 5.98 & 3.65 & 2.77 & 3.93 & 4.18 & 3.90 \\
\hline & 2 & 4.26 & 3.63 & 3.39 & 3.24 & 2.31 & 1.73 & 3.24 \\
\hline & 3 & 5.37 & 4.24 & 4.07 & 5.84 & 5.99 & 3.36 & 4.85 \\
\hline & 4 & 3.57 & 3.86 & 2.78 & 3.10 & - & 3.07 & 3.12 \\
\hline & 5 & - & 2.65 & 4.11 & 2.96 & - & - & 1.39 \\
\hline & Total & 16.48 & 20.36 & 18.00 & 17.91 & 12.23 & 12.34 & 16.50 \\
\hline \multicolumn{2}{|c|}{ Mean of years } & 16.86 & 19.94 & 17.31 & 16.10 & 11.11 & 10.81 & 15.49 \\
\hline \multicolumn{2}{|c|}{$\mathrm{LSD}_{0.05} 1$} & n.s. & n.s. & n.s. & 2.28 & 2.01 & n.s. & n.s. \\
\hline
\end{tabular}

${ }^{1}$ n.s.-not significant.

Average results from the years of the study indicate that the sward of plot 5, where the mixture of the following composition was sown: Festulolium braunii-21.0\%, Lolium perenne-29.0\%, Poa pratensis- $11.0 \%$, Phleum pratense-18.0\%, Dactylis glomerata-21.0\% was characterized by the highest production potential, even when Lolium perenne almost completely fell out of the sward in the second year the study. It is noteworthy that the same mixtures, despite a significant fall out of Lolium perenne from the sward in 2010, in the third year of the study, yielded 42.3\% higher than in 2009 and 60.5\% higher than in 2010 (Table 7). This proves that the species used for mixtures including Festulolium braunii, apart from Lolium perenne, survived the excessive humidity of the habitat well (in winter and early spring 2010) and regenerated the sward, causing high yielding. The lowest yields were obtained from object 2, where the following species were used for regeneration: Festulolium braunii ( $43 \%)$, Poa pratensis $(29 \%)$ and Lolium perenne $(28 \%)$. The annual yield of biomass, obtained from grassland, is a component of yields from individual swaths.

The dry matter yields of mixtures in the second experiment were on average higher than those obtained in the first two years of use in the first experiment, but lower than the average yields from the third year by $6.7 \%$ (Table 7). In this experiment, the mixtures studied, regardless of the year of the study, yielded at a similar level with respect to the object, on which Festulolium braunii was sown in the greatest amount $(50 \%)$, the yield of the remaining mixtures was higher than the average of $2.1 \%$ to $8.0 \%$. In this experiment, also high yields of dry matter were obtained from an object sown with a multi-species mixture of Festulolium braunii-30\%, Lolium perenne-20\%, Poa pratensis-10\% and Dactylis glomerata- $40 \%$.

The results of the dry matter yield obtained in the third experiment (Table 8) prove that under the tested habitat conditions, higher yields are obtained when mixtures with a richer species composition-mixture 3-are used to sow grassland, compared to two-component mixtures of Festulolium braunii and Lolium perenne (on average from the years of the study) by $10.8 \%$ (for a mixture with composition: $34+66 \%$ ) and by $9.1 \%$ for the mixture with $50 \%$ share of the two species in sowing. The results from the six years of the study indicate that using short-lasting species (Lolium perenne and Festulolium braunii) in large quantities in grassland mixtures contributes to an increase in dry matter yields up to four years, while 
in subsequent years to a decrease in average yields by $34.1 \%$-in the fifth and by $35.9 \%$ in the sixth year of the study (Table 8).

It follows from our own long-term studies that Festulolium braunii tolerates varied atmospheric conditions very well during the vegetation period and ensures stable sward yield in mixtures. Lolium perenne, on the other hand, under unfavorable weather conditions decreases its share in the sward, thus decreasing the harvested yield. PCA analysis (Figure 3) showed that the yield of sward dry matter depended most strongly on the share of Lolium perenne. Its place in the studied sward is largely taken by Festulolium braunii, which stabilizes yield but does not affect its growth.

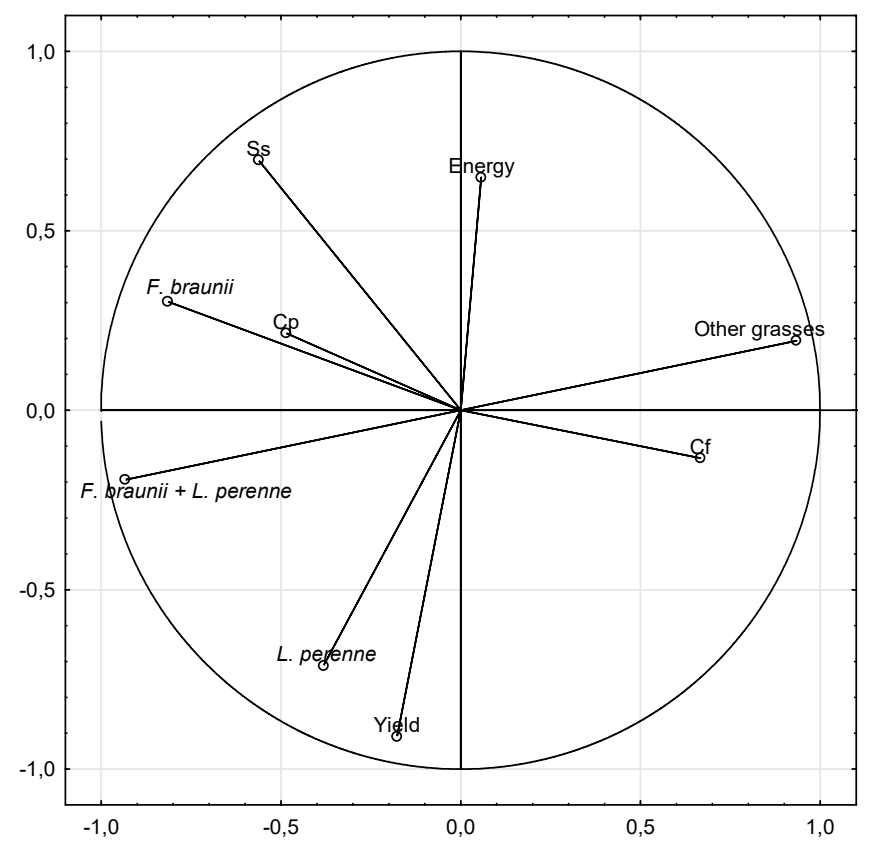

Figure 3. The principle component analysis (PCA) for Lolium perenne, Festulolium braunii, F. braunii + L. perenne, Other grasses abundance and forage value of sward. F. braunii-abundance in the sward, $L$. perenne-abundance in the sward, F. braunii + L. perenne-abundance in the sward, Other grassesabundance in the sward, $\mathrm{Ss}-$ Soluble sugars, $\mathrm{Cp}-$ Crude protein, $\mathrm{Cf}-\mathrm{Crude}$ fiber, Energy-net energy, Yield-sward dry matter yield.

Ward's analysis grouped the objects (grass mixtures) according to similar meadow sward yield quality. The study considered a split with a bond distance of 4 , yielding 4 aggregates of grass mixtures (Figure 4). The extreme groups include grass mixtures in which: (1) the proportion of Lolium perenne decreased greatly and that of Festulolium braunii increased; and (2) the proportion of Lolium prenne and Festulolium braunii did not change much. Such grouping of investigated mixtures indicates that quantitative increase in Festulolium braunii and decrease in Lolium prenne influences yield productivity and quality. The decrease in the proportion of Lolium prenne in the meadow sward largely compensates for the increase in the proportion of Festulolium braunii (stabilizing productivity and yield quality). The introduction of Festulolium braunii to the sward in progressing climatic changes is a good solution to maintain high and good quality sward yields. The results of research on cultivars of this hybrid indicate that dry matter yields are high-from about $6 \mathrm{t} / \mathrm{ha} \mathrm{DM}$ in the absence of mineral fertilisation to $18.13 \mathrm{t} / \mathrm{ha}$ DM with adequate mineral fertilisation $[38,44,69-72]$. This species shows a favorable response to nitrogen fertilisation [73]. 


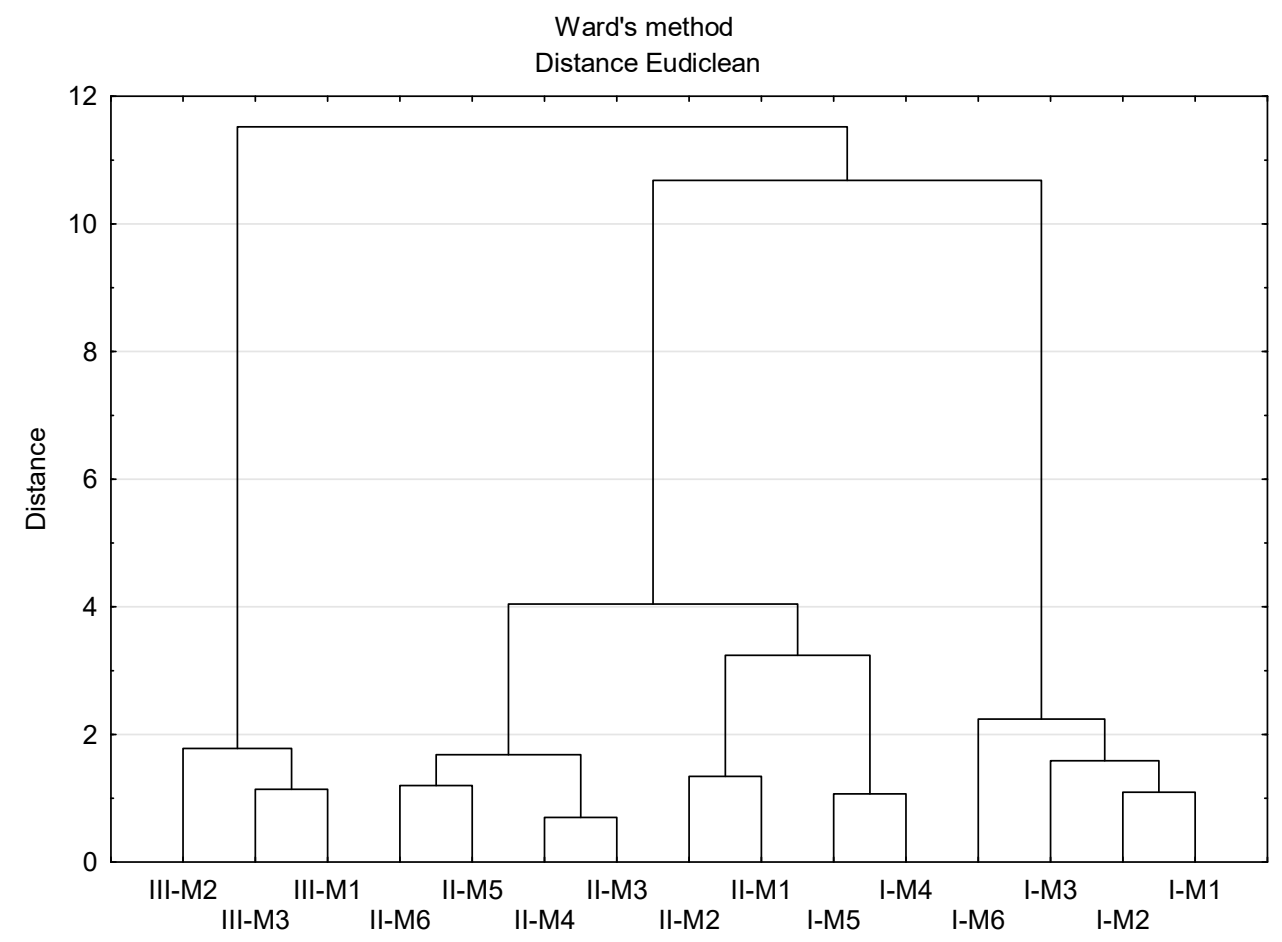

Figure 4. Ward's cluster analysis for grass mixtures (objects) with F. braunii based on average content of: crude protein, soluble sugars, crude fiber, the net energy and sward dry matter yield. The vertical line (linkage distance 4) indicates the cut-off used to form the groups (1-4). Explanations: I-M1: I-experiment no. -M1-grass mixture no.

Gutmane and Adamovich [69], Grønbæk [70] and Østrem, et al. [38] indicate that Festulolium braunii hybrids yield better than Lolium perenne.

\subsection{The Value of Food and Energy of Meadow Sward}

The fodder obtained from a unit of area can be assessed by the quantity or quality of the harvest. According to Staniak and Harasim [49], and Olszewska [74], forage quality is influenced by many factors: sward species composition, plant development stage, soil moisture and nutrient abundance, and weather conditions.

The results of our study presented in Table 9 confirm the research Czyż et al. [75], which showed that the chemical composition, as well as the energy concentration, depends on the floristic composition of the sward. In our study, where the floristic composition of the sward (especially in the first years of the study) was similar to the share of individual species in the mixture used for grassland regeneration, the sward from the multi-component mixture of plot 6, where Festulolium braunii, Lolium perenne, Poa pratensis and Phleum pratense were found in the floristic composition, had the highest crude protein content. In general, the protein content in the research objects ranged from 124 to $158 \mathrm{~g} \cdot \mathrm{kg}^{-1} \mathrm{DM}$ (Table 9).

PCA analysis showed that the crude protein content of forage harvested (under varying weather conditions), was due to the high proportion of Festulolium braunii in the sward.

According to Staniak [76], this hybrid under drought conditions does not respond by lowering the crude protein content of the sward. Moreover, under unfavorable environmental conditions, it favorably influences the development of other grass species more sensitive to the variability of weather conditions, which indirectly affects the protein content of the sward [76]. The crude protein content of Festulolium braunii has a wide range (from $66 \mathrm{~g} \cdot \mathrm{kg}^{-1} \mathrm{DM}$ to $194 \mathrm{~g} \cdot \mathrm{kg}^{-1} \mathrm{DM}$ ) depending on environmental conditions and fertilisation $[49,61,70-72,76]$. Despite the significant amount of crude protein in Festulolium braunii, similar to the content in grasses with high forage value, these amounts are generally insufficient for the nutritional requirements of cattle. The content of crude protein in 
the feed of dairy cattle should not fall below $150 \mathrm{~g} \cdot \mathrm{kg}^{-1} \mathrm{DM}$ [72]. Therefore, this hybrid should occur with legumes and grasses with high protein content. On the other hand, Touno et al. [61] showed that despite lower crude protein in Festulolium braunii than in Phleum pratense $\mathrm{L}$, milk yield in cows was higher in animals fed Festulolium braunii forage.

The crude fiber content ranged from 284 to $307 \mathrm{~g} \cdot \mathrm{kg}^{-1} \mathrm{DM}$. The upper value refers to objects 4 and 5, where the largest share of Dactylis glomerata was found in the sward.

Table 9. The content of organic compounds $\left(\mathrm{g} \cdot \mathrm{kg}^{-1} \mathrm{DM}\right)$ and the concentration of net energy NEL (net energy lactation, $\left.\mathrm{MJ} \cdot \mathrm{kg}^{-1} \mathrm{DM}\right)$ in the sward of the first swath.

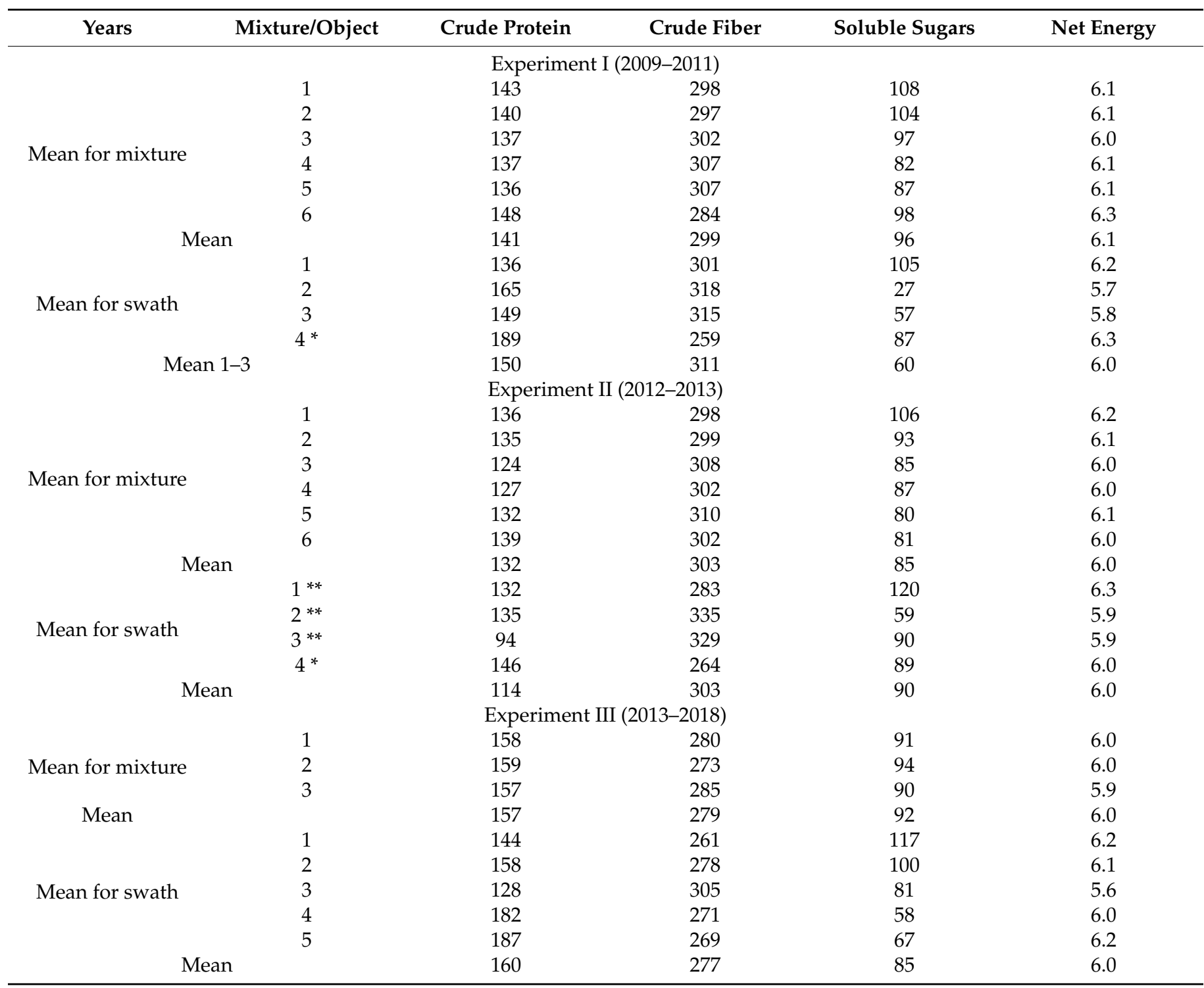

${ }^{*}$ Data from one year; ${ }^{* *}$ Data from two years.

PCA analysis showed that the proportion of Festulolium braunii and Lolium perenne had no effect on crude fibre content in the sward. In contrast, the proportion of other grasses in the sward had a significant effect.

Too high a fibre content worsens the digestibility of the forage. Smaller amounts of crude fibre between $211-243 \mathrm{~g} \cdot \mathrm{kg}^{-1}$ DM in the sward with Festulolium braunii were found by Staniak [76]. At the same time, the author showed that under drought conditions Festulolium braunii contained less crude fibre than under optimal moisture conditions. Touno et al. [61] found $293 \mathrm{~g} \cdot \mathrm{kg}^{-1} \mathrm{DM}$ crude fibre in Festulolium braunii. The author indicated that this hybrid has significantly less fibre than Phleum pratense. Significant 
variations in crude fibre content in Festulolium braunii (from 179 to $320 \mathrm{~g} \cdot \mathrm{kg}^{-1} \mathrm{DM}$ under optimal moisture conditions and from 206 to $241 \mathrm{~g} \cdot \mathrm{kg}^{-1}$ s.m under drought conditions were found by Staniak and Harasim [49].

In terms of soluble sugars (108 and $104 \mathrm{~g} \cdot \mathrm{kg}^{-1} \mathrm{DM}$ ), the sward from objects 1 and 2 in the floristic composition, of which only two species of Festulolium braunii and Lolium perenne were found, was outstanding. This is in consistent with opinion of Ciepiela [77,78], Kozłowski et al. [79], Downing and Gamroth [80], who state that Lolium perenne and Festulolium braunii have a high soluble sugar content among other species. According to Ciepiela [78] Festulolium braunii has a low tendency to accumulate unstructured carbohydrates. A similar opinion of Lolium perenne was expressed by Kozłowski et al. [79] and Piecuch et al. [81].

PCA analysis showed that only the proportion of Festulolium braunii positively shaped the content of water-soluble carbohydrates in the dry matter of the studied sward.

Studies by Gronbak [70], Staniak and Harasim [49], Staniak [76] showed that Festulolium braunii is characterized by a high variation in water-soluble carbohydrate content most often from about 60 to about $100 \mathrm{~g} \cdot \mathrm{kg}^{-1} \mathrm{DM}$, while not exceeding $240 \mathrm{~g} \cdot \mathrm{kg}^{-1} \mathrm{DM}$. No clear effect of drought on carbohydrate content in the hybrid was found $[49,76]$. The high carbohydrate content of Festulolium braunii predisposes this species to form mixtures with high-protein legumes, e.g., limpet, alfalfa [74,76,82]. Forages with a high proportion of water-soluble carbohydrates improve protein digestibility and reduce nitrogen losses, they also have good digestibility, which results in good development of cattle [83,84]. In addition, cattle prefer grasses with a high proportion of carbohydrates [84].

In assessing forage quality, the ratio of water-soluble carbohydrates to crude protein is important, indicating protein availability to cattle [85]. A ratio in the range of $0.8-1.5$ is beneficial for cattle (good nitrogen utilisation), but should not be less than $0.4[82,84,85]$. The tested mixtures with Festulolium braunii had sugar-protein ratios $>0.4$. Equally favorable sugar-protein ratios in mixtures with Festulolium braunii (0.46) were obtained by Sosnowski [82]. On the other hand, Malinowska [71] found a clear effect of fertilisation on the sugar-protein ratio in Festulolium braunii (from 0.704 to 1.53). The ability of Festulolium braunii to accumulate sugars also plays an important role in its resistance to stress conditions, especially water stress [76].

The energy concentration of the sward from all plots was similar: from 6.0 to $6.3 \mathrm{MJ} \cdot \mathrm{kg}^{-1}$ NEL (Table 9). Assessing the fodder value of the meadow sward on the basis of the net energy concentration, it was found that it was at the level recommended for fodder (6 MJ $\left.\cdot \mathrm{kg}^{-1} \mathrm{DM}\right)$, which ensures the proper development of farm animals [86].

PCA analysis showed that the net energy concentration of the harvested sward depended positively to a small extent on the share of Festulolium braunii and other grasses, and negatively on the share of Lolium perenne.

Studies by Gronbaek [70] showed that different cultivars of Festulolium braunii were characterised by energy concentrations ranging from 6.02 to $6.16 \mathrm{MJ} \cdot \mathrm{kg}^{-1} \mathrm{NEL}$ DM and Lolium perenne $6.43 \mathrm{MJ} \cdot \mathrm{kg}^{-1} \mathrm{NEL}$ DM.

In the second year of the study (2010), as a result of very low temperatures in winter and spring floods, the beginning of vegetation was significantly delayed and significant changes in the floristic composition were found: these concerned mainly Lolium perenne, the share of which was very much reduced and was replaced by Dactylis glomerata, Poa pratensis and Phleum pratense and, to a lesser extent, Festulolium braunii (Table 4).

There was also a delay in harvesting the first swath (12 June 2010). Harvesting was carried out in the phase of the dominant species earing. The consequence of the delayed harvest was higher fiber content and lower protein and sugars (Table 9). Jankowska et al. [87] conducting research on a three-cut meadow with a grass community dominated by Festuca pratensis, Dactylis glomerata and Poa pratensis, found $157 \mathrm{~g} \cdot \mathrm{kg}^{-1} \mathrm{DM}$ crude protein, $75.5 \mathrm{~g} \cdot \mathrm{kg}^{-1} \mathrm{DM}$ soluble sugars and $260-290 \mathrm{~g} \cdot \mathrm{kg}^{-1} \mathrm{DM}$ of crude fiber in the sward from the first swath. Comparing the results obtained in our study with the data of Jankowska et al. [87], it should be stated that in the first year of the study (2009), in which four swaths 
were collected, the protein and fiber content in the first swath was consistent with the literature data, while the content of soluble sugars was twice as high. The literature underlines that Festulolium braunii with legumes is a very good feed for cattle [52,76,82].

Biomass production in particular regrowth (swaths) took place under different habitat conditions (groundwater level, air temperature, sunshine) and, therefore, not only were the values of particular parameters different, but also the sward quality was differentiated. The results of our study (Table 9) show, that in the years in which four or five swaths with the best fodder value were collected, the share of Festulolium braunii and Lolium perenne in the floristic composition of individual plots was significant. The highest content of crude protein, soluble sugars and net energy concentration (NEL) and the lowest content of crude fiber were found. Gos and Kitczak [88], conducting research on grasslands located on organic soil, found that harvesting four swaths, biomass was obtained with good parameters, especially of the formation of protein and fiber. According to our assessment of the fodder value of biomass from individual swaths, the best values of analyzed parameters were obtained in the first swath. The greatest differences between swards from particular swaths concerned sugar content. Swaths harvested in summer were characterized by a much lower concentration of soluble sugars than swaths harvested in spring and autumn. The clear decrease in the concentration of unstructured carbohydrates in the summer can be explained by the increased respiration of the plants under high temperature conditions, and mainly sugars are used in this process [89,90]. Similar results were obtained Kozłowski et al. [79], Goliński and Kozłowski [91], Downing and Gamroth [80] and Ciepiela [78].

\section{Conclusions}

1. Festulolium braunii tolerates varied and unfavorable weather conditions (frosts during snowless winters, spring frosts and waterlogging, and droughts) very well and provides a stable good quality sward yield. Lolium perenne, on the other hand, decreases its share in the sward under unfavorable weather conditions.

2. A greater share of Festulolium braunii in the sward affected favorably the content of carbohydrates and protein in the sward, and to a small extent the energy concentration. On the other hand, there was no contribution of Festulolium braunii and Lolium perenne on the crude fibre content in the sward.

3. The proportion of Festulolium braunii and Lolium perenne in the meadow sward affects yield productivity and quality.

4. All the results obtained indicate that, in the analysed habitat, in order to ensure stability of yielding and obtaining fodder of good quality indices, under specific weather conditions of a changing climate, it is justified to apply Festulolium braunii to grass mixtures for grassland regeneration.

Author Contributions: Conceptualization, T.K., H.J., M.B. and R.M.; methodology, T.K., H.J., M.B. and R.M.; formal analysis, T.K., H.J., M.B. and R.M.; resources, M.B.; data curation, T.K., H.J., M.B. and R.M.; writing — original draft preparation, T.K. and R.M.; writing—review and editing, H.J. and M.B.; project administration, T.K. and M.B. All authors have read and agreed to the published version of the manuscript.

Funding: This work was supported by the West Pomeranian University of Technology Szczecin.

Institutional Review Board Statement: Not applicable.

Informed Consent Statement: Not applicable.

Data Availability Statement: West Pomeranian University of Technology Szczecin, Poland.

Conflicts of Interest: The authors declare that they have no known competing financial interest or personal relationships that could have appeared to influence the work reported in this paper.

Compliance with Ethics Requirements: This article does not contain any studies with human or animal subjects. 


\section{References}

1. Huntley, B. Plant species' response to climate change: Implications for the conservation of European birds. IBIS Int. J. Avian Sci. 1995, 137, 127-138. [CrossRef]

2. Schmidt, G.A.; Ruedy, R.A.; Miller, R.L.; Lacis, A.A. Attribution of the present-day total greenhouse effect. J. Geophys. Res. Atmos. 2010, 115. [CrossRef]

3. Kundzewicz, Z.W. Global warming and its impacts. Cosm. Probl. Biol. Sci. 2008, 57, 173-183.

4. Gillett, N.P.; Kirchmeier-Young, M.; Ribes, A.; Shiogama, H.; Hegerl, G.C.; Knutti, R.; Ziehn, T. Constraining human contributions to observed warming since the pre-industrial period. Nat. Clim. Chang. 2021, 11, 207-212. [CrossRef]

5. IPCC. Climate Change 2013: The Physical Science Basis. Contribution of Working Group I to the Fifth Assessment Report of the Intergovernmental Panel on Climate Change; Stocker, T.F., Qin, D., Plattner, G.-K., Tignor, M., Allen, S.K., Boschung, J., Nauels, A., Xia, Y., Bex, V., Midgley, P.M., Eds.; Cambridge University Press: Cambridge, UK; New York, NY, USA, 2013; Volume 12, pp. 1029-1136.

6. Hughes, L. Biological consequences of global warming: Is the signal already apparent. Trends Ecol. Evol. 2000, 15, 56-61. [CrossRef]

7. Byrne, C.; Jones, M.B. Effects of elevated $\mathrm{CO}_{2}$ and nitrogen fertiliser on biomass productivity, community structure and species diversity of a semi-natural grassland in Ireland. Biol. Environ. Proc. R. Ir. Acad. 2002, 102, 141-150. [CrossRef]

8. Nowak, R.S.; Ellsworth, D.S.; Smith, S.D. Functional responses of plants to elevated atmospheric $\mathrm{CO}_{2}-\mathrm{Do}$ photosynthetic and productivity data from FACE experiments support early predictions? New Phytol. 2004, 162, 253-280. [CrossRef]

9. Coulston, J.W.; Riitters, K.H. Preserving biodiversity under current and future climates: A case study. Glob. Ecol. Biogeogr. 2005, 14, 31-38. [CrossRef]

10. Keeling, C.D.; Piper, S.C.; Bacastow, R.B.; Wahlen, M.; Whorf, T.P.; Heimann, M.; Meijer, H.A. Atmospheric $\mathrm{CO}_{2}$ and ${ }^{13} \mathrm{CO}_{2}$ Exchange with the Terrestrial Biosphere and Oceans from 1978 to 2000: Observations and Carbon Cycle Implications. In $A$ History of Atmospheric $\mathrm{CO}_{2}$ and Its Effects on Plants, Animals, and Ecosystems; Baldwin, I., Ed.; Springer: New York, NY, USA, 2005; pp. 83-113. [CrossRef]

11. Jankowska-Huflejt, H.; Domański, J.P. Aktualne i możliwe kierunki wykorzystania trwałych użytków zielonych w Polsce. [Current and possible directions of using permanent grasslands in Poland]. Woda Sr. Obsz. Wiej. 2008, 8, 31-49.

12. Grzegorczyk, S. Produkcyjność mieszanek typu Phalaris arundinacea i Alopecurus pratensis w dolinie Łyny k/Olsztyna [Productivity of Phalaris arundinacea and Alopecurus pratensis mixtures in the Łyna valley near Olsztyn]. Zesz. Probl. Postępów Nauk. Rol. 1993, 412, 115-120.

13. Trąba, C. Rolnicza charakterystyka łąk kostrzewowo-wiechlinowych w dorzeczu Łabuńki. W: Kierunki rozwoju łąkarstwa na tle aktualnego poziomu wiedzy w najnowszych jego działaniach. Konferencja Naukowa [Agricultural characteristics of fescue meadows in the £abuñka river basin. In: Directions of meadow management development against a background of the current level of knowledge in its latest activities]. In Proceedings of the Scientific Conference, Warszawa, Poland, 27-28 September 1994; pp. 380-389.

14. Campbell, B.D.; Stafford-Smith, D.M.; Ash, A.J.; Fuhrer, J.; Gifford, R.M.; Hiernaux, P.; Howden, S.M.; Jones, M.B.; Ludwig, J.A.; Manderscheid, R.; et al. A synthesis of recent global change research on pasture and rangeland production: Reduced uncertainties and theirmanagementimplications. Agric. Ecosyst. Environ. 2000, 82, 39-55. [CrossRef]

15. Milly, P.C.D.; Wetherald, R.T.; Dunne, K.A.; Delworth, T.L. Increasing risk of great floods in a changing climate. Nature 2002, 415 , 514-517. [CrossRef]

16. Dai, A.; Trenberth, K.E.; Qian, T. A global dataset of Palmer drought severity index for 1870-2002: Relationship with soil moisture and effects of surface warming. J. Hydrometeorol. 2004, 5, 1117-1130. [CrossRef]

17. Trenberth, K.E. Changes in precipitation with climate change. Clim. Res. 2011, 47, 123-138. [CrossRef]

18. Marcott, S.A.; Shakun, J.D.; Clark, P.U.; Mix, A.C. A reconstruction of regional and global temperature for the past 11,300 years. Science 2013, 339, 1198-1201. [CrossRef]

19. Thuiller, W.; Lavorel, S.; Araújo, M.B.; Sykes, M.T.; Prentice, I.C. Climate change threats to plant diversity in Europe. Proc. Natl. Acad. Sci. USA 2005, 102, 8245-8250. [CrossRef]

20. Porter, J.R.; Semenov, M.A. Crop responses to climatic variation. Philos. Trans. R. Soc. B Biol. Sci. 2005, 360, 2021-2035. [CrossRef] [PubMed]

21. van der Merwe, N.J. $\mathrm{CO}_{2}$, grasses, and human evolution. In A History of Atmospheric $\mathrm{CO}_{2}$ and Its Effects on Plants, Animals, and Ecosystems; Baldwin, I., Ed.; Springer: New York, NY, USA, 2005; pp. 293-328. [CrossRef]

22. Hopkins, A.; Del Prado, A. Implications of climate change for grassland in Europe: Impacts, adaptations and mitigation options: A review. Grass Forage Sci. 2007, 62, 118-126. [CrossRef]

23. Parry, M.L.; Carter, T.R.; Konijn, N.T. (Eds.) The Impact of Climatic Variations on Agriculture: Volume 1: Assessment in Cool Temperate and Cold Regions; Springer Science \& Business Media: Dordrecht, The Netherlands, 2013.

24. Mitchell, C.E.; Reich, P.B.; Tilman, D.; Groth, J.V. Effects of elevated $\mathrm{CO}_{2}$, nitrogen deposition, and decreased species diversity on foliar fungal plant disease. Glob. Chang. Biol. 2003, 9, 438-451. [CrossRef]

25. Schindler, U.; Steidl, J.; Meuller, L.; Eulenstein, F.; Thiere, J. Drought risk to agricultural land in Northeast and Central Germany. J. Plant Nutr. Soil Sci. 2007, 170, 357-362. [CrossRef] 
26. Soussana, J.F.; Luscher, A. Temperate grasslands and global atmospheric change: A review. Grass Forage Sci. 2007, 62, 127-134. [CrossRef]

27. Malinowski, R.; Paprota, D.; Mielczarek, M. Chemical properties of selected soils of the Ina Valley near Sławęcin village. Environ. Prot. Nat. Resour. J. Inst. Environ. Prot. Natl. Res. Inst. 2016, 27, 23-31. [CrossRef]

28. Bray, E. Plant responses to water deficit. Trends Plant Sci. 2001, 2, 48-54. [CrossRef]

29. Blum, A. Plant Breeding for Water-Limited Environments; Springer: New York, NY, USA, 2011.

30. Staniak, M.; Kocon, A. Forage grasses under drought stress in conditions of Poland. Acta Physiol. Plant. 2015, 37, 116. [CrossRef]

31. Gray, S.B.; Brady, S.M. Plant developmental responses to climate change. Dev. Biol. 2016, 419, 64-77. [CrossRef] [PubMed]

32. Baryła, R. Dynamika zmian składu gatunkowego mieszanek łakowych na glebie torfowo-murszowej w warunkach wieloletniego użytkowania [Dynamics of changes of species composition of meadow-mixtures on pea-muck soil in the conditions of long-term utilization]. Ann. Univ. Mariae Curie Skłodowska Sect. E Agric. 1997, 52, 163-170.

33. Kamiński, J. Plonowanie, zmiany florystyczne i wartość pokarmowa czterech fenologicznie zróżnicowanych mieszanek lakowych na glebie torfowo-murszowej [Yielding, floristic changes and the nutritive value of four phenologically different meadow mixtures on peat-moorsh soil]. Wiadomości Inst. Melior. Użytków Ziel. 2000, 20, 23-37.

34. Kowalczyk, J.; Kamiński, J.; Szuniewicz, K. Zasady kształtowania i utrzymywania wysokoprodukcyjnej runi łąkowej na glebach torfowo-murszowych [Methods of forming and maintaining high productive meadow sward on peat-moorsh soils]. Wiadomości Inst. Melior. Użytków Ziel. 1991, 16, 127-148.

35. Baryła, R. Przydatność Lolium perenne do mieszanek lakowych w siedlisku pobagiennym [Suitability of Lolium perenne for meadow mixtures in postboggy habitat]. Łakarstwo Polsce 2004, 7, 9-20.

36. Thomas, H.; Humphreys, M.O. Progress and potential of interspecific hybrids of Lolium and Festuca. J. Agric. Sci. 1991, 117, 1-8. [CrossRef]

37. Thomas, H.M.; Morgan, W.G.; Humphreys, M.W. Designing grasses with a future-Combining the attributes of Lolium and Festuca. Euphytica 2003, 133, 19-26. [CrossRef]

38. Østrem, L.; Volden, B.; Larsen, A. Morphology, dry matter yield and phenological characters at different maturity stages of $\times$ Festulolium compared with other grass species. Acta Agric. Scand. Sect. B Soil Plant Sci. 2013, 63, 531-542. [CrossRef]

39. Fojtik, A. Methods of grass improvement used at the Plant Breeding Station Hladke Zivotice. Genet. Pol. 1994, 35, $25-31$.

40. Domański, P.; Joks, W. Odmiany festulolium-efekty postępu biologicznego [Festulolium cultivars—Effects of biological progres]. Zesz. Nauk. Akad. Tech. Rol. Bydg. Rol. 1999, 44, 87-94.

41. Nekrošas, S.; Kemešyte, V. Breeding of ryegrass and Festulolium in Lithuania. Zemdirb. Agric. 2007, 94, 29-39.

42. Østrem, L.; Larsen, A. Winter survival, yield performance and forage quality of Festulolium cvs. for Norwegian farming. Grassl. Sci. Eur. 2008, 13, 293-295.

43. Gutmane, I.; Adamovics, A. Influence of nitrogen fertilization rates on Festulolium and Lolium $\times$ boucheanum forage yield and persistency. Grassl. Sci. Eur. 2009, 14, 336-338.

44. Sosnowski, J. The value of production, energy and food of Festulolium braunii (K. Richt.) A. Camus microbiologically and mineral suppled. Fragm. Agron. 2012, 29, 115-122.

45. Matoba, K.; Fushimi, A.; Tamura, R. Festulolium (Festulolium) hinsyu no tokuseihyouka—Ettosei to taishitsusei. Jpn. J. Grassl. Sci. 2001, 47, 138-139.

46. Yamada, T.J.; Forster, W.; Humphreys, M.W.; Takamizo, T. Genetics and molecular breeding in lolium/festuca grass species complex. Grassl. Sci. 2005, 51, 89-106. [CrossRef]

47. Touno, E.; Shingu, H.; Kushibiki, S.; Shinoda, M.; Oshibe, A. Changes in feeding characteristics of the first crop with advancing growth in festulolium (Festulolium braunii) cultivars. Jpn. J. Grassl. Sci. 2006, 52, 176-182.

48. Šimkūnas, A.; Valašinaitè, S.; Mažeika, V. Peculiarities of various Festulolium braunii cultivars development and overwintering. Vagos 2009, 85, 35-38.

49. Staniak, M.; Harasim, E. Changes in nutritive value of alfalfa (Medicago $\times$ varia T. Martyn) and Festulolium (Festulolium braunii (K. Richt) A. Camus) under drought stress. J. Agron. Crop. Sci. 2018, 204, 456-466. [CrossRef]

50. Wilman, D.; Gao, Y.; Leitch, M.H. Some differences between eight grasses within the Lolium-Festuca complex when grown in conditions of severe water shortage. Grass Forage Sci. 1998, 53, 57-65. [CrossRef]

51. Fariaszewska, A.; Aper, J.; Van Huylenbroeck, J.; Baert, J.; De Riek, J.; Staniak, M.; Pecio, Ł. Mild drought stress-induced changes in yield, physiological processes and chemical composition in Festuca, Lolium and Festulolium. J. Agron. Crop. Sci. 2017, 203, 103-116. [CrossRef]

52. Kryszak, J. Plonowanie i jakość mieszanki Festulolium braunii (K. Richter) A. Camus z koniczyną łąkową i lucerną siewną na gruntach ornych [Yielding and quality of Festulolium braunii (K. Richter) A. Camus mixture with red clover and lucerne on arable lands]. Zesz. Probl. Postępów Nauk. Rol. 2001, 479, 173-178.

53. Borowiecki, J. Przegląd prac nad Festulolium braunii (K. Richter) A. Camus [Review on Festulolium braunii (K. Richter) A. Camus]. Pamiętnik Puławski 2005, 140, 15-23.

54. Wolski, K.; Bartmański, A.; Gawęcki, J. Wpływ różnych metod renowacji łąk z wykorzystaniem Festulolium na skład botaniczny i plon runi [Effect of different methods of meadows renovation using Festulolium on botanical composition and yield of sward]. Łakarstwo Polsce 2006, 9, 245-251. 
55. Olszewska, M. Produkcyjność Festulolium braunii (K. Richt.) A. Camus i Festuca pratensis L. uprawianych w mieszankach z Lotus corniculatus L. na tle zróżnicowanego nawożenia azotem [Productivity of Festulolium braunii (K. Richt.) A. Ccamus and Festuca pratensis L. grown in mixtures with Lotus corniculatus L. depending on multiple nitrogen rates]. Acta Sci. Pol. Agric. 2008, 7, 101-114.

56. Pries, M.; Losand, B.; Menke, A.; Tholen, E.; Gruber, L.; Hertwig, F.; Jilg, T.; Kluth, H.; Spiekers, H.; Steingaß, H.; et al. Schätzung des Energiegehaltes in Grasprodukten. Estimation of the energy content in grass products. VDLUFA Schr. Band 2007, 63, 403-411.

57. Filipek, J. Zagadnienie wielkości próbek przeznaczonych do analizy botaniczno-wagowej w doświadczeniach łąkarskich [The size of samples for botanical weight analysis in meadow experiments]. Postępy Nauk. Rol. 1970, 4, 85-98.

58. Ward, J.H., Jr. Hierarchical grouping to optimize an objective function. J. Am. Stat. Assoc. 1963, 58, 236-244. [CrossRef]

59. Humphreys, M.W.; Thomas, H.; Harper, J.; Morgan, G.; James, A.; Ghamari-Zare, A.; Thomas, H. Dissecting drought-And cold tolerance traits in the Lolium-Festuca complex by introgression mapping. New Phytol. 1997, 137, 55-60. [CrossRef]

60. Šimkūnas, A.; Valašinaitè, S.; Pašakinskienè, I. Root growth characteristics of Festuca, Lolium and Festulolium in relation to stress tolerance. Biologija 2007, 1, 64-68.

61. Touno, E.; Kushibiki, S.; Shingu, H.; Shinoda, M.; Oshibe, A.; Oda, S.; Saiga, S. Evaluation of festulolium $(\times$ Festulolium Braunii) 'Paulita' haylage in dairy cows: Nutritive value, dry matter intake, animal performance and rumen degradability. Grassl. Sci. 2011, 57, 51-57. [CrossRef]

62. Oertel, C.; Matzk, F. Introgression of crown rust resistance from Festuca spp. into Lolium multiflorum. Plant Breed. 1999, 118, 491-496. [CrossRef]

63. Ostrowski, R. Festulolium-Miedzyrodzajowy mieszaniec traw pastewnych [Festulolium—Intergeneric hybrid of fodder grasses]. Biul. Inf. Inst. Zootech. 2000, 38, 55-62.

64. Wilkins, P.W.; Humphreys, M.O. Progress in breeding perennial forage grasses for temperate agriculture. J. Agric. Sci. 2003, 140, 129-150. [CrossRef]

65. Kulik, M.; Baryla, R. Zależność udziału Lolium perenne i Trifolium repens w runi pastwiskowej na glebie torfowo-murszowej w warunkach wieloletniego użytkowania [The relationship of share of Lolium perenne and Trifolium repens in pasture sward on peat-muck soil in long-term use]. Łakkarstwo Polsce 2013, 16, 55-67.

66. Baryła, R.; Drozd, M. Plonowanie mieszanek łąkowych z udziałem różnych odmian życicy trwałej (Lolium perenne L.) oraz trwałość tego gatunku w siedlisku pobagiennym [Yielding of meadow mixtures with different cultivars of perennial ryegrass (Lolium perenne L.) and persistence of this species in a post-bog habitat]. Zesz. Probl. Postępów Nauk. Rol. 2001, 479, 15-22.

67. Czyż, H.; Kitczak, T. Walory florystyczne, użytkowe i przyrodnicze słonaw przymorskich [Floristic, Utilitary and Natural Values of Salt-Grasslands on the Sea Coast]. Rocz. Ochr. Sr. 2008, 10, 473-479.

68. Czyż, H.; Kitczak, T.; Bury, M. The characteristics of coastal grassland in West Pomerania. Plant Divers. Evol. 2013, 130, 229-237. [CrossRef]

69. Gutmane, I.; Adamovich, A. Productivity aspects of Festulolium and Lolium x boucheanum cultivars. Grassl. Sci. Eur. 2006, 11, 155-157.

70. Grønbæk, O. Festulolium in Scandinavia. Combining yield, forage quality and persistence. In Kvalita Píce z Travních Porosti̊ a Chov Skotu v Měnících se Ekonomických Podminkách, Sborník z celostátní vědecké konference s mezinárodni účastí konané 14 . řijna 2010 v sále zámku; Kunín, A., Ed.; Výzkumný ústav Rostlinné Výroby: Prague, Czech Republic, 2010; pp. 5-7.

71. Malinowska, E.; Jankowski, K.; Kania, P.; Gałecka, M. The Effect on tytanit foliar application on the yield and nutritional value of festulolium braunii. Agronomy 2020, 10, 848. [CrossRef]

72. Wiśniewska-Kadżajan, B.; Jankowski, K. Effects of the interaction between slurry, soil conditioners, and mineral NPK fertilizers on selected nutritional parameters of Festulolium braunii (K. Richt.) A. Camus. Agron. Res. 2020, 18, 1573-1583. [CrossRef]

73. Adamovies, A.; Platace, R.; Ivanovs, S.; Gulbe, I. The efficiency of nitrogen fertilizer on the matter yield of tall fescue and festulolium grown as feedstock for combustion. Agron. Res. 2019, 17, 2146-2157. [CrossRef]

74. Olszewska, M.; Grzegorczyk, S.; Bałuch-Małecka, A. The effect of different proportions of Medicago media Pers. in mixtures with Festulolium braunii (K. Richt.) A. Camus on the yield and feed value of green fodder. Agric. Food Sci. 2019, 28, 18-26. [CrossRef]

75. Czyż, H.; Trzaskoś, M.; Szydłowska, J.; Malinowski, R. Kształtowanie się zbiorowisk roślinnych na wyspie Chrzązzczewskiej w warunkach oddziaływania wód słonych [Plant communities formation on Chrzaszczewska Island under the influence of saline water]. Acta Agrophysica 2003, 1, 69-75.

76. Staniak, M. Changes in yield and nutritive value of red clover (Trifolium pratense L.) and Festulolium (Festulolium braunii (K. Richt) A. Camus) under drought stress. Agric. Food Sci. 2019, 28, 27-34. [CrossRef]

77. Ciepiela, G.A. Reakcja Wybranych Gatunków Traw na Nawożenie Azotem Stosowanym w Roztworze Mocznika i w Saletrze Amonowej [Reaction of Selected Grass Species to Nitrogen Fertilization with Urea Solution and Ammonium Nitrate]; Monograph Akademia Podlaska: Siedlce, Poland, 2004; Volume 76, pp. 1-80.

78. Ciepiela, G.A. Zawartość węglowodanów strukturalnych i niestrukturalnych oraz ligniny w Dactylis glomerata L. i Festulolium braunii (K. Richt.) A. Camus zasilanych biostymulatorem Kelpak SL i azotem [Content of structural and nonstructural carbohydrates and lignin in Dactylis glomerata L. and Festulolium braunii (k. richt.) a. Camus supplied by biostimulator kelpak SL and nitrogen]. Nauka Przyr. Technol. 2014, 8, 1-12.

79. Kozłowski, S.; Golińska, B.; Goliński, P. Cukry a wartość użytkowa roślin łąkowych [Sugars and the use value of meadow plants]. Pamiętnik Puławski 2001, 125, 131-138. 
80. Downing, T.T.W.; Gamroth, M.J. Nonstructural carbohydrates in cool-season grasses. Or. State Univ. Ext. Serv. Spec. Rep. 2007, 11, $1-6$.

81. Piecuch, A.; Krzywiecki, S.; Szyszkowska, A. Wartość energetyczna runi pastwiska trawiastego i trawiasto-koniczynowego określona według metody NEI i INRA 88 [Energy value of grass and grass-clover pasture sward determined by NEI and INRA 88]. Biul. Oceny Odmian 1997, 29, 185-189.

82. Sosnowski, J. Wartość paszowa mieszanek Festulolium braunii z kończyną łąkową i lucerna mieszańcowa zasilanych użyźniaczem glebowy [The feed value of Festulolium braunii mixtures with red cloverand alfalfa supplied with soil's fertilizer]. Łakarstwo Polsce 2011, 14, 127-135.

83. Miller, L.A.; Moorby, J.M.; Davies, D.R.; Humphreys, M.O.; Scollan, N.D.; MacRae, J.C.; Theodorou, M.K. Increased concentration of water-soluble carbohydrate in perennial ryegrass Lolium perenne L.): Milk production from late-lactation dairy cows. Grass Forage Sci. 2001, 56, 383-394. [CrossRef]

84. Edwards, G.R.; Parsons, A.J.; Rasmussen, S.; Bryant, R.H. High sugar ryegrasses for livestock system in New Zealand. Proc. N. Z. Grassl. Assoc. 2007, 69, 161-171. [CrossRef]

85. Simili da Silva, M.S.; Tremblay, G.F.; Bélanger, G.; Lajeunesse, J.; Papadopoulos, Y.A.; Fillmore, S.A.; Jobim, C.C. Energy to protein ratio of grass-legume binary mixtures under frequent clipping. Agron. J. 2013, 105, 482-492. [CrossRef]

86. Krzywiecki, S. Znaczenie traw w żywieniu zwierzat gospodarskich. W: Perspektywy hodowli zwierząt w Polsce. Materiały Konferencyjne [The importance of grasses in farm animal nutrition]. In Proceedings of the Perspectives for Animal Breeding in Poland Conference Materials, Wrocław, Poland, 18-19 September 1995; pp. 33-40.

87. Jankowska, J.; Ciepiela, G.A.; Kolczarek, R.; Jankowski, K. Wpływ rodzaju nawozu mineralnego i dawki azotu na plonowanie i wartość pokarmową runi łąki trwałej [Influence of mineral fertilizer type and nitrogen dose on yield and fodder value of sward of permanent grassland]. Pamiętnik Puławski 2008, 147, 125-138.

88. Gos, A.; Kitczak, T. Plenność łak trwałych będących zapleczem suszarni [Productivity of permanent meadows as the basis for a grass drier]. Zesz. Probl. Postępów Nauk. Rol. 1998, 462, 101-106.

89. Nowacki, E. Genotyp i nawożenie a jakość paszy dla przeżuwaczy [Genotype and plant nutrition, fodder quality for ruminant animals]. Zesz. Probl. Postępów Nauk. Rol. 1981, 241, 37-53.

90. Watts, K.A. Carbohydrates in forage: What is a Safe Grass? In Proceedings of the 2008 Kentucky Equine Research Conference "Facing Today's Nutritional Challenges; Advanced Tucky Equine Research: Versailles, KY, USA, 2008; pp. 1-13.

91. Golińska, B.; Kozłowski, S. Zmienność w występowaniu składników organicznych i mineralnych w Phalaris arundinacea [Variation in the occurrence of organic and mineral compounds in Phalaris arundinacea]. Ann. Univ. Mariae Curie Skłodowska Sect. E Agric. 2006, 61, 353-360. 